\title{
Pulmonary-Hepatic vascular Disorders (PHD)
}

\author{
R. Rodríguez-Roisin*, M.J. Krowka*, Ph. Hervé , M.B. Fallon ${ }^{+}$, on behalf of the ERS Task Force \\ Pulmonary-Hepatic Vascular Disorders (PHD) Scientific Committee
}

ERS Task Force PHD Scientific Committee: J.A. Barberá, J.O. Cáneva, M.B. Fallon, J.C. García-Pagán, J.C. García-Valdecasas, Ph. Hervé, S. Kawut, M.J. Krowka, D. Lebrec, D. Navarro, M. Navasa, M.A.E. Ramsay, J. Rodés, R. Rodríguez-Roisin, G. Rolla, O. Sitbon, P.D. Wagner

\section{CONTENTS}

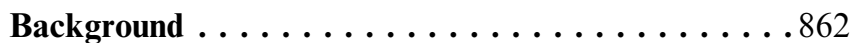

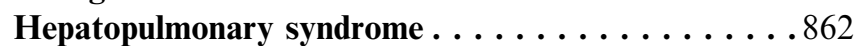

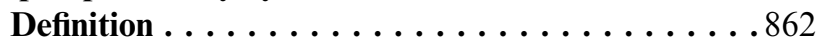

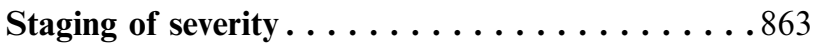

Natural history and outcome. . . . . . . . . . . . . . . . . . . . . . . .

Pathophysiology . . . . . . . . . . . . . . 863

Pathology . . . . . . . . . . . . . . . . . . . . . . . . . . . . . . . . . . . . . . . . . .

Pathogenesis . . . . . . . . . . . . . . . . . . . . . . . . . . . . . . . . . . . . . . . .

Clinical diagnosis. . . . . . . . . . . . . . . . . . . . . . . . . . . . . . . . . .

Symptoms and physical examination. . . . . . . . . . . . . . . . . .

Lung function tests . . . . . . . . . . . . . . . . . . . . . . . . . . . . . . .

Haemodynamics . . . . . . . . . . . . . . 865

Biochemistry and noninvasive exhaled

biomarkers . . . . . . . . . . . . . . . . . . . . . . . . . . . .

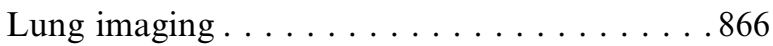

Contrast-enhanced echocardiography . . . . . .866

Transoesophageal echocardiography . . . . . . . . . .866

Perfusion lung scanning . . . . . . . . . . . . . . . . . . . 866

Pulmonary angiography . . . . . . . . . . . 866

Thoracic computed tomographic scanning . .866

Screening . . . . . . . . . . . . . . . . . . . . . . . . . . . . . . . . . . . . . . .

Management . . . . . . . . . . . . . . . . . . . . . . . . . . . . . . . . .

Pharmacological treatment. . . . . . . . . . . . . 867

Nonpharmacological treatment . . . . . . . . . . . . . 867

Long-term oxygen therapy . . . . . . . . . . . 867

Transjugular intrahepatic portosystemic shunt 867

Cavoplasty ... . . . . . . . . . . . . . . . . . . . . . . . . . . . . .

Embolisation. . . . . . . . . . . . . . . . . . .867

Orthotopic liver transplantation . . . . . . . . . . . . .868

Task Force recommendations . . . . . . . . . 868

Research prospects. . . . . . . . . . . . . . . . . . . . . . . . . . . . . . . . .

Portopulmonary hypertension . . . . . . . . . . . . . . . . . . . . . . . . . . .

Definition . . . . . . . . . . . . . . 868
Staging of severity . . . . . . . . . . . . . . . . 8868

Natural history and outcome. . . . . . . . . . . 868

Pathology . . . . . . . . . . . . . . . . . . . . . . . 869

Pathophysiology and pathogenesis . . . . . . . . . 869

Vasoproliferation ... . . . . . . . . . . . . . . . . . . . . . . . . . . . . . . . . . . .

Genetics . . . . . . . . . . . . . . . . . . . 869

Inflammation . . . . . . . . . . . . . . . 869

Neurohormones . . . . . . . . . . . . . . . . . . . . . . . . . . . . . . . . . . . . .

Clinical diagnosis and screening. . . . . . . . . . . . . . . . . . . .

Symptoms and physical examination. . . . . . 870

Transthoracic Doppler echocardiography . . . . 870

Haemodynamics . . . . . . . . . . . . . . . . . . . 870

Acute vasodilator testing . . . . . . . . . . .870

Pulmonary haemodynamic subsets . . . . . . . . . . . . . . . . . . . .

Management . . . . . . . . . . . . . . . . . . . . . . . . . . . . . .

Pharmacological treatment. . . . . . . . . . . . . . . . . 871

Nonspecific therapy. . . . . . . . . . . . . . 8871

Diuretics . . . . . . . . . . . . . . . . . . . . . . . . . . . . .

Cardiac glycosides . . . . . . . . . . . . . . . . . . . . . . . . . . . . . . . .

Vasodilator therapy. . . . . . . . . . . . . . . . . . . . . . . . . . . .

Calcium channel blockers . . . . . . . . . . 871

Nitrates . . . . . . . . . . . . . . .871

Continuous i.v. epoprostenol infusion . . . . 871

Other prostacyclin analogues (treprostinil,

iloprost and beraprost) . . . . . . . . . . 8872

Endothelin receptor antagonists (bosentan) .872

Nonpharmacological treatment . . . . . . . . . . . . . 872

Long-term oxygen therapy . . . . . . . . . . . 872

Transjugular intrahepatic portosystemic shunt. . . . . . . . . . . . . . 872

Orthotopic liver transplantation . . . . . . . . . . . . .872

Task Force recommendations . . . . . . . . . . . . . . . . . . . . . . .

Research prospects. . . . . . . . . . . . . . 8873

\footnotetext{
*Service of Pneumology, Hospital Clínic, Institut d'Investigacions Biomèdiques August Pi i Sunyer (IDIBAPS), Universitat de Barcelona, Barcelona, Spain. ${ }^{\#}$ Mayo Clinic, Rochester, MN, and ${ }^{+}$University of Alabama, Birmingham, AL, USA. "Surgical Centre Lannelongue, Le Plessis Robinson, France.

Correspondence: R. Rodríguez-Roisin, Servei de Pneumologia, Hospital Clínic, Villarroel 170, 08036-Barcelona, Spain. Fax: 34 932275404. E-mail: rororo@clinic.ub.es
} 
"The tantalizing problem of the connective link in cirrhotic patients between oxygen unsaturation and possible arteriovenous shunting in the lungs remains unsolved, and any relation between arterial unsaturation and pulmonary vasodilation remains obscure."

\section{BERTHELOT et al. [1]}

"Portal venous hypertension coexisted with pulmonary arterial hypertension. These observations suggested two questions: What was the origin of the pulmonary vascular changes? Was there a possible relationship between these pulmonary vascular lesions and abnormalities in the portal venous system?"

NAEYE [2]

\section{Background}

Owing to the success of orthotopic liver transplantation (OLT), there has been increasing recognition of the importance of pulmonary vascular complications of hepatic disease states. Such vascular complications, namely hepatopulmonary syndrome (HPS) and portopulmonary hypertension (PPHTN), are commonly present as dyspnoea and are not always easily distinguished from nonpulmonary symptoms caused by manifestations of advanced liver disease (such as anaemia, ascites and muscle wasting). More importantly, since the late 1980s, experience has taught that such complications influence survival and candidacy for OLT. Currently, OLT is the only effective treatment for improving outcome in patients with HPS, a life-threatening condition whose prevalence can approach $20 \%$ in some series of patients awaiting OLT. PPHTN, pulmonary arterial hypertension (PAH) occurring in the setting of liver disorders, another dramatic pulmonary-hepatic vascular condition, has a prevalence in the order of $5 \%$ in hepatic patients submitted to OLT. Unlike in HPS, in the moderate-to-severe stages of PPHTN, OLT is not widely recommended, even being regarded a contraindication due to its negative perioperative and postoperative impact. As a consequence, a difficult pharmacological vasodilatory strategy becomes mandatory before proceeding to OLT. Notwithstanding, it is now evident that knowledge and understanding from diagnosis to management of these two distinct entities are rudimentary, such that underdiagnosis, undertreatment and inconsistent management are common worldwide.

During the 2000 European Respiratory Society (ERS) Annual Congress held in Florence, Italy (August 2000), a symposium on these two disorders, entitled "Advances in Understanding Pulmonary Complications in Hepatic Diseases", was organised under the auspices of the Clinical Physiology and Integrative Biology ERS Assembly. The participants in this symposium, all experts in pulmonary and hepatic diseases, unanimously agreed to apply for an ERS Task Force on Pulmonary-Hepatic Vascular Disorders (PHD), which was approved and funded by the Scientific Committee in October 2001. The recommendations in this report were essentially developed during two workshops. The first was held within the context of the European Association for the Study of the Liver (EASL) Annual Meeting, in Madrid, Spain (April 2002), and the second in Barcelona, Spain (January 2003).

This ERS Task Force on PHD had three major objectives: 1) to increase awareness of both HPS and PPHTN in the medical community in order to minimise the growing impact of their morbidity and mortality; 2) to improve diagnosis and management of HPS and PPHTN through a major concerted effort by specialists involved in all facets of their clinical care; and 3) to stimulate the minimal programme of research interest in these two disorders.

\section{Hepatopulmonary syndrome}

\section{Definition}

HPS is defined as an arterial oxygenation defect induced by intrapulmonary vascular dilatations (IPVD) associated with hepatic disease [3-6]. The vascular component characteristically includes diffuse or localised dilated pulmonary capillaries and, less commonly, pleural and pulmonary arteriovenous communications. All in all, HPS encompasses a clinical triad characterised by arterial deoxygenation, IPVD and liver disorder. Although HPS is predominantly seen in middle-aged patients without sex difference, it can also occur in children [7, 8].

The most common hepatic disorder leading to HPS is liver cirrhosis, irrespective of aetiology [3-6], although HPS has also been observed in many other chronic, and even acute, hepatic conditions [3-13]. The pulmonary gas exchange abnormality is characterised by arterial deoxygenation that may be mild, moderate or severe $[3,5,13-16]$. There is an increased alveolar-arterial oxygen tension difference $\left(\mathrm{PA}-\mathrm{a}, \mathrm{O}_{2}\right)$. In contrast, arterial carbon dioxide retention (arterial carbon dioxide tension $\left.\left(\mathrm{Pa}, \mathrm{CO}_{2}\right) \geqslant 6.0 \mathrm{kPa}(\geqslant 45 \mathrm{mmHg})\right)$ is never present $[3-5,13,14]$. On the contrary, since patients with advanced liver disease usually hyperventilate, hypocapnia $\left(P \mathrm{a}, \mathrm{CO}_{2}<4.7 \mathrm{kPa}(<35 \mathrm{mmHg})\right)$ and respiratory alkalosis are common. Calculation of $\mathrm{PA}-\mathrm{a}, \mathrm{O}_{2}$ is one of the most sensitive approaches for the detection of early arterial deoxygenation $[3,5]$, since $\mathrm{PA}-\mathrm{a}, \mathrm{O}_{2}$ can increase before arterial oxygen tension $\left(\mathrm{Pa}_{\mathrm{a}} \mathrm{O}_{2}\right)$ itself becomes abnormally low. At sea level and while breathing room air, a resting $P A-a, O_{2}$ of $\geqslant 2.0 \mathrm{kPa}$ $(\geqslant 15 \mathrm{mmHg})$ can be considered abnormal $[15,16]$, but, for patients aged $>64$ yrs, a $P A-a, O_{2}$ of $\geqslant 2.7 \mathrm{kPa}(\geqslant 20 \mathrm{mmHg})$ can be recommended (table 1) [14]. However, an increased $P A-a, \mathrm{O}_{2}$ alone is not sufficient to confirm the existence of HPS [13]. IPVD must also be present and are considered to exist when pulmonary capillary diameter ranges $15-60 \mu \mathrm{m}$, being the major structural derangement in HPS [1]. Contrastenhanced echocardiography (CEE) and perfusion lung scanning using technetium-99m-labelled macroaggregated albumin ( ${ }^{99 \mathrm{~m}}$ TcMAA) are the two most well-accepted approaches for assessing IPVD [3-6]. Although some imaging techniques, such as pulmonary angiography and conventional or high-resolution computed tomography (HRCT) scanning, may also provide information about the shape, appearance and distribution of pulmonary vessels [17], their diagnostic accuracy has not yet been sufficiently well established. This

Table 1.-Diagnostic criteria for hepatopulmonary syndrome

Liver disease

$P \mathrm{~A}-\mathrm{a}, \mathrm{O}_{2}{ }^{\#, \oplus} \geqslant 15 \mathrm{mmHg}$

Positive CEE

$P A-a, \mathrm{O}_{2}$ : alveolar-arterial oxygen tension difference; CEE: contrastenhanced echocardiography. ${ }^{\#}$ : abbreviated formula: $P \mathrm{~A}, \mathrm{O}_{2}-P \mathrm{a}, \mathrm{O}_{2}=$ $F \mathrm{I}, \mathrm{O}_{2}\left(\mathrm{Patm}-\mathrm{PH}_{2} \mathrm{O}\right)-P \mathrm{a}, \mathrm{CO}_{2} / \mathrm{RER}-\mathrm{Pa}, \mathrm{O}_{2}$, where $P \mathrm{~A}, \mathrm{O}_{2}$ is alveolar oxygen tension, $\mathrm{Pa}, \mathrm{O}_{2}$ arterial oxygen tension, $\mathrm{FI}, \mathrm{O}_{2}$ inspiratory oxygen fraction, $P$ atm atmospheric pressure, $P_{\mathrm{H}_{2} \mathrm{O}}$ water vapour partial pressure and RER exchange respiratory ratio (assumed to be 0.8 ) [14]. : for patients aged $>64$ yrs, a cut-off value for $P \mathrm{~A}-\mathrm{a}, \mathrm{O}_{2}$ of $\geqslant 20 \mathrm{mmHg}$ can be recommended [14]. $1 \mathrm{mmHg}=0.133 \mathrm{kPa}$. 
combination of arterial deoxygenation, IPVD and liver disease is so unique that it supports the diagnosis of HPS even in the presence of associated chronic cardiopulmonary diseases, such as chronic obstructive pulmonary disease (COPD), bronchial asthma or idiopathic pulmonary fibrosis, which can also cause (or aggravate) arterial gas exchange abnormalities, including hypoxaemia with or without hypercapnia [18].

\section{Staging of severity}

Staging of the severity of HPS is important because severity influences survival [19-22], and is useful in determining the timing and risks of OLT [5, 21-23]. A classification of the severity of HPS based on oxygenation abnormalities in four stages is proposed (table 2) [3-6, 13, 14]. More severe HPS causes greater clinical symptoms [13, 14], probably affects quality of life and signals the need to consider specific therapeutic interventions (i.e. long-term oxygen therapy and embolotherapy) to offset the deleterious effects of tissue hypoxia [24]. Assessment of the severity of IPVD is difficult by means of CEE because this technique does not provide a quantitative evaluation. Extrapulmonary uptake of ${ }^{99 m}$ TcMAA can be quantified, but the procedure has not been sufficiently standardised beyond a few centres. The sensitivity of both approaches for the detection of anatomical pulmonary arteriovenous communications or diffuse or localised vascular dilatations alone is similar [25].

\section{Natural history and outcome}

Definite statements concerning the natural history of HPS have been limited by two factors. First, few HPS patients are followed in any single centre. A multicentric database for OLT candidates described $20 \%$ of HPS patients who were denied this surgical procedure due to extrapulmonary comorbid conditions, with follow-up not reported [26]. In the largest single-centre-based series to date, in HPS patients $\left(\mathrm{Pa}, \mathrm{O}_{2}\right.$ cut-off of $\left.<9.3 \mathrm{kPa} \quad(<70 \mathrm{mmHg})\right)$ who did not undergo OLT until 1988 [27], median survival was 41 months following diagnosis of HPS, and the longest survivor not having undergone transplantation lived $>10$ yrs. Mortality is usually due to complications of hepatic disease, as opposed to a primary respiratory event. A more recent prospective study demonstrated a shorter median survival ( $\sim 11$ months) with similar causes of death [23].

Secondly, OLT interrupts or modulates the natural course of HPS. Not only has OLT become the treatment of choice for HPS in many centres, but successful OLT has also resulted in complete resolution of HPS in the majority of survivors of the early post-surgical period $[6,27]$. Preliminary data suggests, however, slow recovery of arterial hypoxaemia,

Table 2. - Grading of severity of hepatopulmonary syndrome ${ }^{\#}$

\begin{tabular}{lcc}
\hline Stage & ${\mathrm{PA}-\mathrm{a}, \mathrm{O}_{2}{ }^{\oplus, \S} \mathrm{mmHg}}$ & $\mathrm{Pa}, \mathrm{O}_{2}{ }^{+, \S} \mathrm{mmHg}$ \\
\hline Mild & $\geqslant 15$ & $\geqslant 80$ \\
Moderate & $\geqslant 15$ & $<80-\geqslant 60$ \\
Severe & $\geqslant 15$ & $<60-\geqslant 50$ \\
Very severe & $\geqslant 15$ & $<50\left(<300\right.$ on $\left.100 \% \mathrm{O}_{2}\right)$ \\
\hline
\end{tabular}

$P A-a, \mathrm{O}_{2}$ : alveolar-arterial oxygen tension difference; $\mathrm{Pa}, \mathrm{O}_{2}$ : arterial oxygen tension. \#: all with positive contrast-enhanced echocardiography; ${ }^{\prime}$ normal range $4-8 \mathrm{mmHg}$; ${ }^{+}$: normal range $100-80 \mathrm{mmHg}$ (breathing room air at rest and at sea level) [14]; \$: for patients aged $>64$ yrs, a cut-off value for $P \mathrm{~A}-\mathrm{a}, \mathrm{O}_{2}$ of $\geqslant 20 \mathrm{mmHg}$ and $\mathrm{Pa}, \mathrm{O}_{2}$ of $<70 \mathrm{mmHg}$ can be recommended [14]. $1 \mathrm{mmHg}=0.133 \mathrm{kPa}$. but long-term survival following OLT in some HPS patients $[6,27]$. Sporadic cases of PPHTN after OLT-induced HPS resolution have been reported $[6,28,29]$.

In patients with portal hypertension, the natural history of HPS is not sufficiently understood, since its precise pathogenic mechanisms remain unsettled [6]. Moreover, the prevalence of HPS varies widely between pulmonary and liver centres. In patients with cirrhosis, the mean prevalence of subclinical HPS is $15 \%[3,30]$, depending on the cut-off values of $\mathrm{Pa}, \mathrm{O}_{2}$ used to define the entity [14] and/or means of calculation of $P \mathrm{~A}-\mathrm{a}, \mathrm{O}_{2}$ to diagnose HPS (table 1) $[3,5,13,14]$. In patients with unusual hepatic diseases, the prevalence of HPS is unknown, although it may be anticipated to be extremely low, given the lower incidence of these hepatic conditions compared with that of liver cirrhosis. In chronic viral hepatitis with or without cirrhosis, the prevalence of HPS is $\sim 10 \%$ [9]. The prevalence of HPS in OLT candidates $(18 \%)$ is elevated [13] and has been reported to be as high as $28 \%$ in Budd-Chiari syndrome [11]. Rare cases of HPS in combination with PPHTN before OLT have also been documented (Ph. Hervé and R. Rodríguez-Roisin, personal communications) [31]. The behaviour of $\mathrm{Pa}, \mathrm{O}_{2}$ in advanced cirrhotic patients without HPS remains unknown [32], as does the outcome of HPS with coexisting cardiopulmonary comorbid conditions.

\section{Pathophysiology}

The major primary structural disturbance in HPS is dilatation of the pulmonary pre-capillary and post-capillary vessels that allows mixed venous blood to pass either very quickly or even directly into the pulmonary veins [3-6]. Absent or reduced pulmonary vascular tone with impaired hypoxic vasoconstriction may also occur $[33,34]$. There are three well-known intrapulmonary determinants of arterial deoxygenation, namely alveolar ventilation-perfusion $\left(V^{\prime} \mathrm{A} /\right.$ $Q^{\prime}$ ) imbalance, increased intrapulmonary shunt (i.e. nonventilated or zero $V^{\prime} \mathrm{A} / Q^{\prime}$ units) and diffusion impairment to oxygen, essentially reflecting a diffusion-perfusion defect [35], and all may be present in advanced HPS $[3-6,33,34,36-40]$. By contrast, the role of direct portopulmonary venous communications to arterial deoxygenation is negligible [3]. However, the relative contributions of the former three determinants appear to vary. Although it is agreed that $V^{\prime} \mathrm{A} / Q^{\prime}$ mismatching is the pivotal mechanism for arterial deoxygenation since it fits well with the presence of lung regions in which alveoli are normally ventilated but overperfused, the relevance of the other two factors remains somewhat speculative [41]. An added conceptual difficulty is the reconciliation of the presence of elevated levels of increased intrapulmonary shunt (i.e. $\geqslant 20 \%$ of cardiac output $\left.\left(Q^{\prime}\right)\right)$ despite the active $\mathrm{Pa}, \mathrm{O}_{2}$ response to $100 \%$ oxygen (i.e. $\mathrm{Pa}, \mathrm{O}_{2}>40 \mathrm{kPa}(>300 \mathrm{mmHg})$ ) observed in many patients. Diffusion impairment to oxygen, as shown by a greater predicted (according to the multiple inert gas elimination technique) [42] than measured $\mathrm{Pa}_{2} \mathrm{O}_{2}[40,41]$ while breathing room air, is also present in advanced HPS, a mechanism also consistent, in part, with the common finding of a low diffusing capacity of the lung for carbon monoxide $(D \mathrm{~L}, \mathrm{CO})$. It is of note that the presence of an elevated $Q^{\prime}$ facilitates, in part, this favourable $P \mathrm{a}, \mathrm{O}_{2}$ response to breathing $100 \%$ oxygen, other things being equal. Presumably, $D \mathrm{~L}, \mathrm{CO}$ is reduced because the distance between the alveoli and the red cells in the central stream of the dilated pulmonary microvessels is too great for complete equilibration of carbon monoxide with haemoglobin. Although capillary blood volume is likely to be increased, diffusion impairment to 
oxygen may be aggravated, in part, by a high $Q^{\prime}$, resulting in a shorter transit time of the red blood cell and, hence, contributing to the development of a diffusion-perfusion imbalance [35]. Nevertheless, this pulmonary gas exchange status is still consistent with the coexistence of the three mechanisms of hypoxaemia mentioned previously, their individual roles varying according to HPS severity (table 2) [3]. Thus, early HPS stages with normoxaemia $\left(\mathrm{Pa}, \mathrm{O}_{2}\right.$ $\geqslant 10.6 \mathrm{kPa} \quad(\geqslant 80 \mathrm{mmHg}))$ and increased $P A-\mathrm{a}, \mathrm{O}_{2}$ $(\geqslant 2.0 \mathrm{kPa}(\geqslant 15 \mathrm{mmHg}))$ alone or with moderate levels of hypoxaemia $\left(P \mathrm{a}, \mathrm{O}_{2} \geqslant 8.0-<10.6 \mathrm{kPa}(\geqslant 60-<80 \mathrm{mmHg})\right)$ may be associated with mild $V^{\prime} \mathrm{A} / Q^{\prime}$ inequality and modest intrapulmonary shunt $\left(<10 \%\right.$ of $\left.Q^{\prime}\right)$, but rarely with diffusion impairment, whereas, in severe HPS $\left(\mathrm{Pa}_{\mathrm{a}} \mathrm{O}_{2} \geqslant 6.7-<8.0 \mathrm{kPa}\right.$ $(\geqslant 50-60 \mathrm{mmHg}))$, and also in the most severe hypoxaemic stages $\left(P \mathrm{a}, \mathrm{O}_{2}<6.7 \mathrm{kPa}(<50 \mathrm{mmHg})\right)$, all three determinants of arterial deoxygenation can coexist. Hyperventilation, by increasing alveolar oxygen tension, and high $Q^{\prime}$, by raising mixed venous oxygen tension, may diminish the reduction in $P a, \mathrm{O}_{2}$ [43]. The influence of coexisting chronic lung disorders, such as COPD or idiopathic pulmonary fibrosis, of relatively common occurrence in HPS patients, on arterial desaturation remains unsettled [18].

\section{Pathology}

Several pathological abnormalities have been documented in the pulmonary vasculature of cirrhotic patients with HPS [44]. These abnormalities include diffuse or localised dilatation of alveolar pre-capillary and post-capillary vessels, pleural (surface) and pulmonary anatomical artery-to-vein communications and portopulmonary venous anastamoses [1]. However, the few detailed pathological studies were carried out before the standardisation of a universal definition of HPS and prior to the availability of imaging modalities used to detect IPVD. Nonetheless, dilatation of capillary vessels in alveolar regions $[1,45]$ is a central prerequisite and the principal pathophysiological hallmark of arterial deoxygenation in both human and experimental HPS [46, 47]. In addition, in animal models, intravascular accumulation of macrophages in the pulmonary microcirculation and increased numbers of pulmonary capillaries have been shown, suggesting a vasculogenic response [47, 48]. Whether similar changes occur in humans and are important pathogenically has not been resolved.

\section{Pathogenesis}

Most clinical cases have been reported in the setting of liver cirrhosis and portal hypertension, although controversy exists over whether the frequency and severity of HPS correlate with the degree of hepatic synthetic dysfunction and portal hypertension $[6,19,25,49]$. The evidence that HPS occurs in both extrahepatic portal venous obstruction [50] and hepatic venous outflow obstruction without cirrhosis (extrinsic liver disease) [51] shows that severe hepatic dysfunction and cirrhosis are not absolutely required for HPS to develop. In addition, the finding that HPS can occur in the setting of acute [52] and chronic noncirrhotic hepatitis [7, 9] demonstrates that portal hypertension may not be present in all cases. Finally, a clinical syndrome similar to HPS is observed in congenital disorders without liver injury in which either hepatic venous blood flow does not reach the lung [53] or portal venous blood reaches the inferior vena cava without passing through the liver [54], supporting the theory that factors either produced or metabolised in the liver can modulate the pulmonary vasculature.

Enhanced pulmonary production of nitric oxide (NO) has been implicated in the development of IPVD in cirrhotic patients with HPS [55-59]. Exhaled NO levels are increased in HPS patients and normalise after OLT [56-58], as HPS resolves or is minimised. However, the mechanism of increased endogenous NO production and its relationship to the presence of portal hypertension, the hyperdynamic circulation and the degree of liver injury, remains uncertain. In addition, whether other mediators might contribute to IPVD has not yet been studied.

Experimentally, chronic common bile duct ligation (CBDL) is the only identified rat model of HPS [60, 61], whereas partial portal vein ligation has been used as a control intervention in which both portal hypertension and a hyperdynamic circulation develop without hepatic injury and subsequent HPS [61]. Early studies focused on the vasoconstrictor role of eicosanoids and the increased numbers of intravascular macrophage-like cells [48, 60, 62]. Subsequent work identified increased pulmonary vascular endothelial (eNOS) and inducible (iNOS; in macrophages) NO synthase expression and activity as the origin of the increase in pulmonary NO production [63-68]. Intravenous $N^{\mathrm{G}}$-nitro-Larginine methyl esther (L-NAME) improved hypoxaemia in CBDL rats, thereby supporting the pathogenic role of excessive pulmonary NO release in HPS [69]. Further studies have demonstrated that increased hepatic production and release of low levels of endothelin (ET)-1 is one mechanism for triggering an increase in pulmonary eNOS levels and vasodilatation after CBDL $[64,65]$. This is associated with a selective increase in pulmonary vascular $\mathrm{ET}_{\mathrm{B}}$ receptor expression in cirrhosis and portal hypertension, an event that appears to enhance $\mathrm{ET}_{\mathrm{B}}$ receptor-mediated ET-1-induced NO production [66]. The roles of other enzymes and mediators investigated have recently refocused interest on the accumulation of intravascular macrophages. An increase in pulmonary iNOS expression [63] has been observed in CBDL [67], predominantly in intravascular macrophage-like cells, and was felt to be an important source of NO. Furthermore, treatment of CBDL with norfloxacin decreased macrophage accumulation and normalised iNOS but not eNOS levels [68], hence, supporting a role for bacterial translocation in pulmonary macrophage accumulation and its contribution to IPVD. Pentoxifylline, an inhibitor of tumour necrosis factor (TNF)- $\alpha$ production in macrophages [70], also prevented HPS in the rat model [71], thereby supporting its pathogenic role. Recent work suggests that ET- 1 and TNF- $\alpha$ can both interact in the development of experimental HPS [72]. More recently, the findings of increased haem oxygenase1 expression and carbon monoxide production in CBDL support their role in the progression of IPVD [73, 74]. Figure 1 highlights some of these mechanisms.

\section{Clinical diagnosis}

Symptoms and physical examination. Shortness of breath is a common symptom when arterial hypoxaemia associated with HPS develops in the setting of chronic liver disease. The development of HPS does not appear to correlate uniformly with the severity of underlying liver disease, as characterised by the Child-Pugh score [19, 49]. Characteristic but not pathognomic of HPS, however, is the typical complaint of platypnoea (increased dyspnoea from the supine to upright position) [5] and the associated finding of orthodeoxia (decrease in $\mathrm{Pa}, \mathrm{O}_{2} \geqslant 5 \%$ or $\geqslant 4 \mathrm{mmHg}$ from the supine to upright position) $[36,75]$, whose mechanism has been recently 
a)

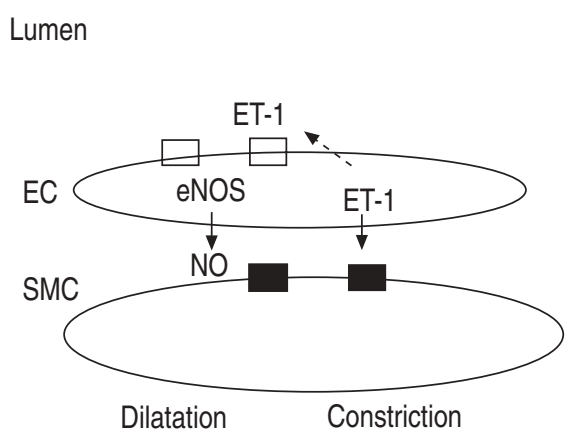

b)

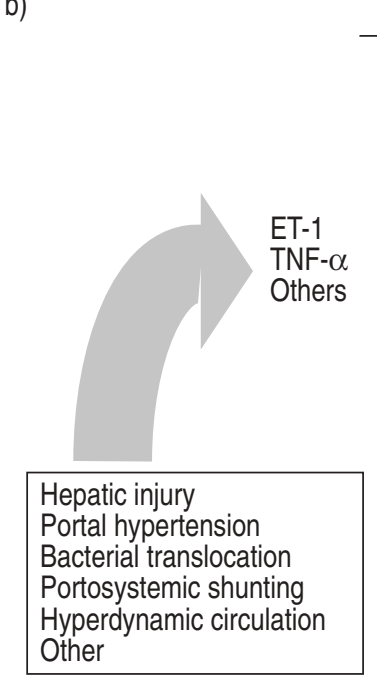

Initiation Maintenance Progression

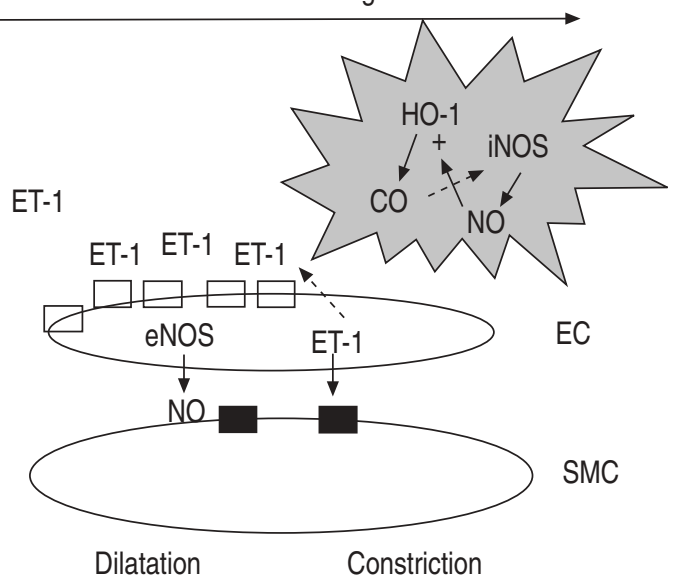

Fig. 1.- Working model of molecular alterations in the pulmonary microcirculation in experimental hepatopulmonary syndrome (HPS). a) In the normal microvasculature, a balance of vasoconstrictive and vasodilatory factors, including paracrine endothelin (ET)-1-mediated vasoconstriction through the $\mathrm{ET}_{\mathrm{A}}$ receptor ( $\left.\mathbf{\square}\right)$ on smooth muscle cells (SMCs) and ET-1-mediated vasodilatation mediated through the ET $\mathrm{B}_{\mathrm{B}}$ receptor $(\square)$ linked to endothelial nitric oxide synthase (eNOS) in endothelial cells (ECs), maintain tone. b) During the development of HPS, a number of alterations, both directly and indirectly related to hepatic injury and portal hypertension, result in the production or release of mediators into the venous circulation, where they influence the pulmonary microcirculation. Increased expression of pulmonary endothelial $\mathrm{ET}_{\mathrm{B}}$ receptors and increased hepatic production and release of ET-1 contribute to an increase in eNOS expression and enhanced nitric oxide (NO) production in the microvascular endothelium during the initiation of HPS. Tumour necrosis factor (TNF)- $\alpha$-mediated accumulation of intravascular macrophage-like cells also occurs after chronic common bile duct ligation. Haem oxygenase (HO)-1 and inducible nitric oxide synthase (iNOS) expression increase in these cells and contribute to the progression of HPS. CO: carbon monoxide.

clarified [75]. Early exertional dyspnoea may evolve into dyspnoea at rest as hypoxaemia progresses. Fatigue resulting from anaemia and hepatic dysfunction may be difficult to distinguish from HPS-induced hypoxaemia. Spider naevi, digital clubbing, and cyanosis of the lips and nail beds are consistent findings in advanced HPS, although they are not entirely specific $[5,33,76]$. Clinicians should also be aware that common chronic pulmonary comorbid conditions, in particular COPD, bronchial asthma and idiopathic pulmonary fibrosis, coexist in approximately a third of HPS patients $[18,23,77]$. Extrapulmonary complications of rightto-left pulmonary communications, such as the development of a brain abscess [78, 79] or intracranial haemorrhage [80], and hypoxaemia-induced polycythaemia [81], have been reported. Information on health status is not available.

Lung function tests. Both forced spirometric results and static lung volumes (by plethysmography or helium-dilution) are characteristically within normal limits in HPS in the absence of pulmonary comorbid conditions [12, 22, 82]. Although mild-to-moderate ventilatory abnormalities may be present in some patients $[22,82]$, a moderately to severely reduced $D \mathrm{~L}, \mathrm{CO}$ after adequate correction for anaemia [83] appears to be a common functional marker of HPS $[3,13]$. Compared to the full reversibility of all functional and clinical outcomes, a sustained low $D$ L,CO in HPS patients 1 yr after successful OLT is an intriguing finding [84, 85], which could be related to collagen tissue deposition in pulmonary capillary and venule walls, as shown in a single post mortem study [86]. Since the mechanism of low $D$ L,CO remains unsettled, this gas exchange descriptor is not recommended for the screening evaluation of HPS (see below).

Arterial blood gas tensions, assessed at rest while breathing room air and in the sitting position by arterial puncture or through an indwelling arterial catheter, are mandatory for both the diagnosis and staging of severity of HPS, and encompass a wide spectrum of abnormalities from a simple increase in $\mathrm{PA}-\mathrm{a}, \mathrm{O}_{2}$ alone to very severe, life-threatening levels of hypoxaemia, usually associated with hypocapnia. During exercise, patients with HPS achieve lower peak oxygen uptakes than cirrhotics without HPS, with more hypoxaemia and an elevated dead space, hence, suggesting that abnormal pulmonary ciculation contributes to further exercise limitation in HPS [87]. Pulse oximetry for the assessment of arterial oxygen saturation $\left(\mathrm{Sa}, \mathrm{O}_{2}\right)$ is useful in the follow-up of patients with moderate-to-severe HPS, particularly children, before OLT, but is not sufficiently accurate to replace the detailed information provided by routine arterial blood gas tension determination (because of the shape of the oxyhaemoglobin dissociation curve).

Haemodynamics. A hyperkinetic circulatory state, with high $Q^{\prime}$ and low systemic vascular resistance and pulmonary vascular resistance (PVR), is present in $30-50 \%$ of cirrhotic patients and generally correlates with the Child-Pugh score [88-92], especially in patients with moderate-to-severe HPS. Patients with portal hypertension show a low median PVR with a wide range [88]. Systemic and pulmonary vasodilatation in cirrhosis and portal hypertension appears to be the consequence of a widespread decrease in vascular tone [92, 93] that results in impaired responsiveness to vasoconstrictors [94, 95]. Hypoxic pulmonary vasoconstriction is absent or mitigated in $\sim 30 \%$ of patients with advanced cirrhosis, with or without associated HPS, and appears to become less evident as liver disease worsens [33, 34, 96-98]. Whether or not a progressive loss of pulmonary vascular tone as liver disease deteriorates contributes to IPVD and the development of HPS remains controversial [22, 98, 99].

Biochemistry and noninvasive exhaled biomarkers. No serum test of hepatic function has been shown to be of value in the diagnosis of HPS [3-6]. However, serum progesterone and oestradiol levels are generally elevated in HPS [99] and both hormones have been correlated with the appearance of spider 
naevi, a finding also related to haemodynamic and gas exchange abnormalities in cirrhotic patients [33]. Sex hormone levels and IPVD return to normal after OLT, suggesting a pathogenic role in HPS [99]. Serum nitrite/nitrate levels are increased in liver cirrhosis and this is related to endotoxaemia [100]. Increased exhaled NO levels, derived from the alveolar region [101,102], are observed in patients with advanced cirrhosis with and without HPS [57, 58, 103], and correlate with the abnormally increased $P A-a, O_{2}$ [57] and high $Q^{\prime}$ [103]. Partial or complete resolution of clinical and functional markers of HPS after using different inhibitors and/or interventions that block the effects of NO, such as methylene blue [59, 104] and L-NAME [105], or following smoking [106] and OLT [56], sporadically or anecdotally reported, support the idea that increased endogenous pulmonary NO could play a pivotal role in the development of arterial deoxygenation. Further clinical studies are needed to establish the precise utility of exhaled NO in the clinical workup of HPS. To date, no data are available regarding exhaled gas condensates [107].

Lung imaging. Contrast-enhanced echocardiography. Transthoracic echocardiography with contrast enhancement (CE-TTE) provides a sensitive, noninvasive and qualitative screening approach for the detection of IPVD, the central defining structural characteristic of HPS [108], and is considered the gold standard for the diagnosis of HPS. It is commonly accomplished by hand agitation of $10 \mathrm{~mL}$ normal saline, resulting in microbubbles ( $\leqslant 90 \mu \mathrm{m}$ in diameter), which are injected into an upper extremity vein. Detection of microbubbles within the left atrium is considered positive CEE. Microbubbles are physiologically trapped and absorbed by normal alveoli during the first pass and should not appear in the left atrium. Following microbubble appearance in the right atrium, immediate appearance in the left atrium (within less than three cardiac cycles) suggests an intra-atrial right-to-left communication, whereas delayed appearance in the left heart cavities (within greater than three cardiac cycles) implies definite IPVD [5, 108]. Although positive CE-TTE results are found in $11-47 \%$ of patients with liver disease (with or without associated HPS), only $32-59 \%$ of these patients have arterial hypoxaemia [49, 109-113]. Patients with positive CE-TTE results and normal arterial oxygenation may have forme fruste (or clinically silent) HPS, but their outcome remains unknown [114]. Indocyanine green solution (microbubble size $\leqslant 90 \mu \mathrm{m}$ ) [109] or a modified gelatin solution (which creates microbubbles of $10 \pm 2 \mu \mathrm{m})[115]$ are the alternative contrast agents used and possibly contribute to the different prevalence findings [14].

Transoesophageal echocardiography. Alternatively, transoesophageal echocardiography with contrast enhancement (CE-TEE) may be superior to CE-TTE for the diagnosis of IPVD in cirrhotic patients with HPS, being more sensitive and showing better correlation with $\mathrm{Pa}, \mathrm{CO}_{2}$ and $D$ L, CO than in patients without HPS [116]. Further, it can definitively discern the passage of microbubbles through an interatrial pathway versus microbubble entrance into the left atrium from the pulmonary veins. However, CE-TEE is more expensive, requires sedation and poses a theoretical risk in patients with oesophageal varices, which may be present in patients with liver disease. Since CETTE has been shown to be more sensitive than lung perfusion scanning for the detection of IPVD [19], with the additional advantage that it can be conducted as part of routine echocardiographic screening for pulmonary hypertension by Doppler assessment of tricuspid systolic peak regurgitant jet velocity (see Portopulmonary hypertension section), it can be recommended as the best choice for screening for both HPS and PPHTN.

Perfusion lung scanning. Whole-body ${ }^{99 \mathrm{~m}}$ TcMAA scanning allows for the detection of IPVD, along with their quantification, detecting areas with both low and zero $V^{\prime} \mathrm{A} /$ $Q^{\prime}$ units [49, 117]. Since macroaggregates are $>20 \mu \mathrm{m}$ in diameter, they are normally trapped in the pulmonary vascular network. In patients with intracardiac shunt or IPVD, radiolabelled particles bypass, or pass through, the pulmonary vascular bed and are transported to and retained by extrapulmonary regions, such as the brain, kidneys, spleen and liver. The major disadvantage of perfusion lung scanning relative to CE-TTE is its inability to differentiate between intracardiac communications and IPVD. In addition, the sensitivity of lung perfusion scanning is lower than that of CE-TTE in detecting HPS [49]. However, the radionuclide approach allows the quantification of IPVD by assessment of systemic and pulmonary uptake, and various indices have been proposed [19, 118]. In addition, increased systemic distribution of radiolabelled particles does not occur in chronic associated respiratory comorbid conditions, whereas CEE results remain positive, such that the ${ }^{99}{ }^{2}$ TcMAA approach may be of help in evaluating the contribution of HPS to arterial hypoxaemia in these patients. One validated perfusion (or shunting) index not, however, used routinely takes into account the ${ }^{99 \mathrm{~m}}$ TcMAA activity of the liver and the brain $[19,20,49]$, with a cut-off value of $\geqslant 6 \%$ of $Q^{\prime}$ when intracardiac communications or IPVD are present. The assessment of IPVD using the isotopic method provides shunt estimates that often exceed the functional estimates of shunt provided by the conventional $100 \%$ oxygen method [25]. This is because IPVD may continue to participate in alveolar gas exchange, especially when the driving oxygen pressure is increased by the administration of high oxygen concentrations. Finally, the combination of quantifying the severity of arterial deoxygenation and the degree of intrapulmonary shunting indices by ${ }^{99 \mathrm{~m}}$ TcMAA may offer complementary information for the stratification of HPS patients at greater risk of OLT mortality [19-21].

Pulmonary angiography. One pulmonary angiographic study in a small subset of HPS patients demonstrated two angiographic patterns: type I, or diffuse, and type II, or focal [17]. The type I pattern was subdivided into a "minimal" pattern, characterised by normal vessels or fine diffuse spidery arterial vascular abnormalities, and an "advanced" pattern, with a diffuse spongy or blotchy appearance. The type II pattern, more infrequent, consisted of focal arteriovenous communications similar to those seen in hereditary haemorrhagic telangiectasia. Patients with "advanced" type I and type II patterns may exhibit a poor response to oxygen breathing $\left(\mathrm{Pa}, \mathrm{O}_{2} \quad<40 \mathrm{kPa} \quad(<300 \mathrm{mmHg})\right)$. Under these circumstances, the latter subset of patients may be considered for vascular embolisation, as type II lesions are not reversible and the patients may be at risk of cerebral embolism and/or abscess [17, 78, 79]. Type I lesions can also be successfully embolised with subsequent marked increases in $\mathrm{Pa}, \mathrm{O}_{2}$, as shown in a case report [24].

Thoracic computed tomographic scanning. There is little information regarding the use of conventional thoracic computed tomography (CT) scans for the diagnosis of 
HPS. In one small study, CT demonstrated that the peripheral pulmonary arteries were significantly dilated compared with controls and normoxaemic cirrhotic patients [119]. However, a retrospective study did not confirm these results [120]. A thoracic HRCT scan may be useful for excluding coexistent chronic respiratory conditions when HPS is suspected [18].

\section{Screening}

The major screening steps for HPS are summarised in figure 2, and are particularly recommended for all OLT candidates and for hepatic patients who have shortness of breath. Arterial blood gas levels, including calculation of $P A-a, \mathrm{O}_{2}$ using the abbreviated formula (table 1), are measured, and, if an abnormally increased $P A-a, O_{2}$ is confirmed, with or without coexisting hypoxaemia, both CEE and a complete set of lung function tests (forced spirometry with bronchodilator response, static lung volumes and $D \mathrm{~L}, \mathrm{CO}$ ) are carried out. A negative CEE result excludes the diagnosis of HPS, whereas a positive CEE result establishes the diagnosis of HPS, irrespective of the presence or absence of intrinsic cardiopulmonary disease. In the event of normoxaemic HPS (increased $\mathrm{PA}-\mathrm{a}, \mathrm{O}_{2}$ alone with positive $\mathrm{CEE}$ results), arterial blood gas levels should be measured, at least once a year, to detect any abnormal $\mathrm{Pa}, \mathrm{O}_{2}$ change, and/or if symptoms (essentially dyspnoea) appear. In addition, thoracic HRCT may be carried out, irrespective of the detection of any abnormal lung function tests, in order to rule out underlying subclinical chronic pulmonary disorders. Complementarily, the perfusion index calculated from a whole-body ${ }^{99 \mathrm{~m}} \mathrm{TcMAA}$ scan [49] can be helpful in estimating the outcome after OLT (see below).

If hypoxaemia is mild to moderate $\left(\mathrm{PA}-\mathrm{a}, \mathrm{O}_{2} \geqslant 2.0 \mathrm{kPa}\right.$ $(\geqslant 15 \mathrm{mmHg}) \quad$ and/or $\quad P \mathrm{a}, \mathrm{O}_{2} \geqslant 8.0-<10.6 \mathrm{kPa} \quad(\geqslant 60$

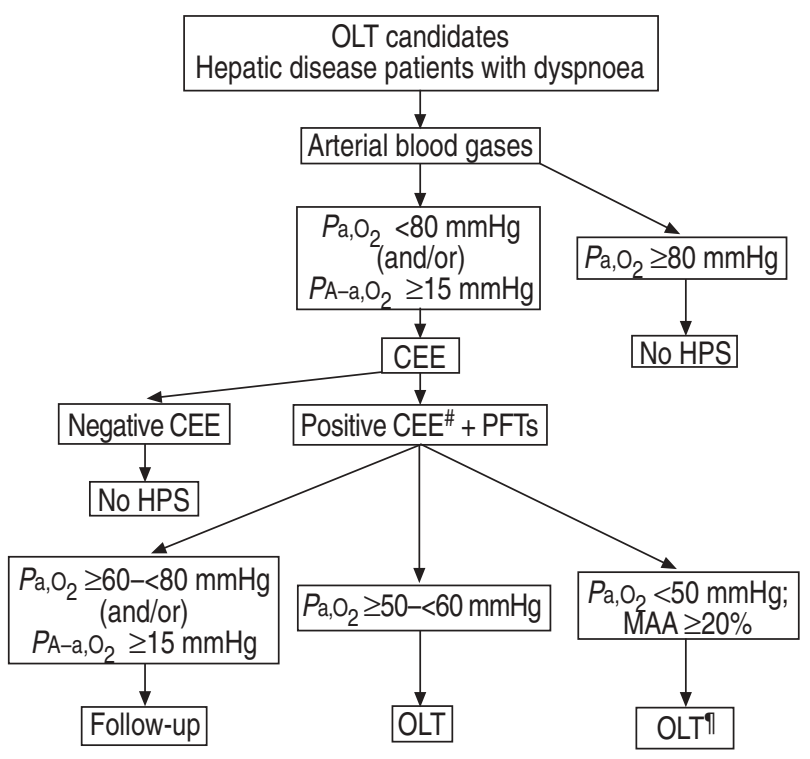

Fig. 2. - Algorithm for screening and therapeutic decisions in hepatopulmonary syndrome (HPS). OLT: orthotopic liver transplantation; $P_{\mathrm{a}, \mathrm{O}_{2}}$ : arterial oxygen tension; $P \mathrm{~A}-\mathrm{a}, \mathrm{O}_{2}$ : alveolar-arterial oxygen tension difference; CEE: contrast-enhanced echocardiography; PFT: pulmonary function test; MAA: macroaggregated albumin. \#: highresolution thoracic computed tomographic scanning is highly recommended in order to exclude chronic respiratory comorbid conditions; : high risk for post-operative OLT mortality. $1 \mathrm{mmHg}=0.133 \mathrm{kPa}$
$<80 \mathrm{mmHg}$ )), periodic follow-up is recommended, at least once a year, with assessment of lung function, including pulse oximetry and/or arterial blood gas levels if necessary $\left(\mathrm{Sa}, \mathrm{O}_{2}\right.$ $<89 \%$ ). If hypoxaemia progressively deteriorates in a symptomatic (breathless) patient, then OLT can be considered. Likewise, if hypoxaemia is severe $\left(\mathrm{Pa}, \mathrm{O}_{2} \geqslant 6.7-<8.0 \mathrm{kPa}\right.$ $(\geqslant 50-<60 \mathrm{mmHg})$ ), consideration of OLT is vital. If the hypoxaemia is very severe or extreme $\left(\mathrm{Pa}, \mathrm{O}_{2}<6.7 \mathrm{kPa}\right.$ $(<50 \mathrm{mmHg})$ ) [21] and/or cardiopulmonary comorbid conditions exist [18], OLT needs to be considered on an individual basis after full assessment of the severity and prognosis of the associated extrahepatic disorders. Lung biopsy specimens are not required for diagnosis of HPS as IPVD are not reliably detected in tissue specimens. However, if coexisting idiopathic lung fibrosis is suspected in the face of potential OLT indication on the basis of severe HPS, then lung biopsy can be required to determine suitability for OLT.

\section{Management}

Pharmacological treatment. A number of small uncontrolled trials using various classes of drug, such as somatostatin analogue [17], $\beta$-blockers [121, 122], cyclooxygenase inhibitors [123, 124], glucocorticoids and immunosuppressors (cyclophosphamide) [125], pulmonary vasoconstrictors (almitrine) [126, 127], NO inhibitors [59, 104-106, 128], inhaled NO [129, 130], antimicrobials [68, 131] and garlic preparation [132], for the treatment of HPS have been reported. None of the studies, however, demonstrated consistent improvement in oxygenation and/or IPVD, as all were of inadequate size to test efficacy. In addition, rare spontaneous recovery has been observed in HPS [7, 133], although the mechanism remains uncertain. Future randomised placebo-controlled multicentric trials are needed in order to further investigate these and new therapeutic interventions.

Nonpharmacological treatment. Long-term oxygen therapy. HPS patients with severe hypoxaemia $\left(\mathrm{Pa}, \mathrm{O}_{2}<8.0 \mathrm{kPa}\right.$ $(<60 \mathrm{mmHg}))$ at rest are commonly seen and should receive continuous long-term low-flow oxygen therapy. No data are available, however, regarding the efficacy, compliance, tolerance and cost-effectiveness of such a therapeutic approach.

Transjugular intrahepatic portosystemic shunt. Portal hypertension appears to play a central role in the pathogenesis of HPS. Accordingly, a reduction in portal pressure might be beneficial in HPS [134-137]. To date, only a few case reports using transjugular intrahepatic portosystemic shunt (TIPS) for HPS have been published, and have shown variable short-term effects on pulmonary gas exchange [134, 137]. Therefore, insufficient data are available to support TIPS as a compassionate therapeutic approach in HPS [138].

Cavoplasty. This effective decompressive treatment in patients with suprahepatic inferior vena cava obstruction causing Budd-Chiari syndrome showed promise in reversing coexistent HPS [11]. Similarly, venous decompression by abscess drainage resolved HPS in a single case with BuddChiari syndrome [11]

Embolisation. Coil embolisation (embolotherapy) in type II angiographic pattern HPS [17] has been reported to improve arterial oxygenation (as a temporary measure) in a single case report [24]. 
Orthotopic liver transplantation. Complete resolution of HPS following OLT has been observed in $>80 \%$ of reported cases, and many centres currently view HPS as an indication for OLT [139-145], particularly in the paediatric population [146-149]. Morbidity may be higher after OLT in severe HPS, based on pre-OLT severity of hypoxaemia and abnormal extrapulmonary ${ }^{99 m}$ TcMAA uptake [21, 22]. Such patients, depending on local surgical and post-OLT expertise facilities, might benefit from referral to highly specialised transplantation centres with significant HPS experience. Spontaneous recurrence of HPS [150, 151] and development of PPHTN before [31] or following OLT for HPS [6, 29] have been reported, but appear to be rare events. Liver transplantation from living donors for HPS has been shown to be successful in children [152], but no data are available in adults.

\section{Task Force recommendations}

The major Task Force recommendations concerning the diagnosis and treatment of HPS are summarised in table 3.

\section{Research prospects}

1) Natural history, incidence and prevalence, particularly in the most advanced hepatic patients, remain controversial. All these aspects should be investigated prospectively through large multicentric studies, including the influence of long-term oxygen therapy.

2) The relevance and implications of positive CEE results suggestive of underlying IPVD, in the context of normal gas exchange, are completely ignored. There is a need for studies investigating the importance of this positive hallmark and its impact on the natural history of HPS.

3) The potential of experimental HPS models and their interplay with clinical studies need to be explored. This would facilitate greater insight into the pathogenic mechanisms of HPS. OLT is the only reliable treatment for full or partial resolution of HPS. Multicentric prospective studies of the natural history of OLT outcomes of HPS need to be developed.

4) Given the pathogenic role of some mediators, such as $\mathrm{NO}$ and ET, clinical trials of long-term inhaled NOS and $\mathrm{ET}_{\mathrm{B}}$ receptor antagonists, $\mathrm{TNF}-\alpha$ inhibitors and antibiotics are necessary research topics that could result in new therapeutic approaches.

Table 3.-Summary of major Task Force recommendations for hepatopulmonary syndrome (HPS)

Screen for HPS using arterial blood gas levels in hepatic patients who: 1) complain of dyspnoea, or 2) are OLT candidates

Proceed to CEE if: 1) $\mathrm{Pa}_{2} \mathrm{O}_{2}<80 \mathrm{mmHg}$, and/or 2)

$P \mathrm{~A}-\mathrm{a}, \mathrm{O}_{2} \geqslant 15 \mathrm{mmHg}$

Diagnosis of HPS must be completed with: 1) PFTs, 2) thoracic

HRCT scan, and 3) ${ }^{99 \mathrm{~m}}$ TcMAA shunting index (if available)

No medical treatment for HPS is available except for

symptomatic measures (i.e. long-term oxygen therapy)

Consider firm indication for OLT if $\mathrm{Pa}, \mathrm{O}_{2} \geqslant 50-60 \mathrm{mmHg}$; OLT should be considered on an individual basis if $\mathrm{Pa}, \mathrm{O}_{2}<50 \mathrm{mmHg}$

OLT: orthotopic liver transplantation; CEE: contrast-enhanced echocardiography; $\mathrm{Pa}_{\mathrm{a}} \mathrm{O}_{2}$ : arterial oxygen tension; $\mathrm{PA}-\mathrm{a}, \mathrm{O}_{2}$ : alveolar-arterial oxygen tension difference; PFT: pulmonary function test; HRCT: highresolution computed tomography; ${ }^{99 \mathrm{~m}} \mathrm{TcMAA}$ : perfusion lung scanning technetium-99m-labelled macroaggregated albumin. $1 \mathrm{mmHg}=0.133 \mathrm{kPa}$.

\section{Portopulmonary hypertension}

\section{Definition}

PPHTN can be defined as a PAH associated with portal hypertension, with or without hepatic disease [153-156]. Diagnosis of PPHTN is based on pulmonary haemodynamic criteria obtained via right heart catheterisation $[6,153]$. Diagnostic criteria for PAH include a mean pulmonary arterial pressure $(\mathrm{Ppa})$ of $>25$ (at rest) or $>30 \mathrm{mmHg}$ (during exercise), with a mean pulmonary artery occlusion pressure (mPAOP) of $<15 \mathrm{mmHg}[153,154,157]$. A moderate increase in $P$ pa $(25-35 \mathrm{mmHg})$ is seen in up to $20 \%$ of patients with cirrhosis and portal hypertension [158]. This increase in $P$ pa is most commonly caused by increases in $Q^{\prime}$ (despite reduced PVR) and/or in blood volume (increased mPAOP) [158, 159], without pulmonary vascular remodelling. Less commonly, moderate-to-severe PAH with extensive pulmonary vascular remodelling (increased PVR) develops [6, 153, 158, 160, 161]. In order to distinguish between these two forms of PAH, criteria have evolved for the diagnosis of PPHTN (table 4) [162-165]. These haemodynamic criteria are consistent with the definitions and classification proposed by the 3rd World Symposium on Pulmonary Arterial Hypertension [166]. Unlike HPS, arterial deoxygenation is not a major functional feature of PPHTN.

\section{Staging of severity}

A classification of severity of PPHTN is proposed (table 5), based on $P$ pa [167]. Such severity staging correlates with the increased mortality following OLT in moderate-to-severe PPHTN (pre-OLT Ppa of $>35 \mathrm{mmHg}$ ) $[164,168]$.

\section{Natural history and outcome}

Initially described in 1951 , the existence of portal hypertension and development of PAH are not coincidental [169]. Pulmonary hypertension has been reported in $0.13 \%$ of unselected patients versus $0.73 \%$ of patients with cirrhosis

Table 4.-Diagnostic criteria for portopulmonary hypertension

Liver disease (causing clinical portal hypertension)

$P$ pa $>25 \mathrm{mmHg}$

mPAOP $<15 \mathrm{mmHg}$

$\mathrm{PVR}^{\#}>240 \mathrm{dyn} \cdot \mathrm{s} \cdot \mathrm{cm}^{-5}\left(3.0 \mathrm{mmHg} \cdot \mathrm{L}^{-1} \cdot \mathrm{min}^{-1}\right.$; cut-off may vary $\left.{ }^{\top}\right)$

$P$ pa: mean pulmonary arterial pressure; mPAOP: mean pulmonary arterial occlusion pressure; PVR: pulmonary vascular resistance. \#. $80(P$ pa-mPAOP $) / Q^{\prime}\left(\right.$ in $\left.\mathrm{L} \cdot \mathrm{min}^{-1}\right)$, where $Q^{\prime}$ is cardiac output; ${ }^{\top}$ : classical textbook criteria for normal PVR vary up to $240 \mathrm{dyn} \cdot \mathrm{s}^{\cdot} \cdot \mathrm{cm}^{-5}$; several liver transplantation centres have previously used a cut-off of $>120 \mathrm{dyn} \cdot \mathrm{s} \cdot \mathrm{cm}^{-5}$ as abnormal, but some patients in the $120-240 \mathrm{dyn} \cdot \mathrm{s} \cdot \mathrm{cm}^{-5}$ range exhibit normal $P$ pa or increased mPAOP. Evidence-based data favour $>240$ dyn $\cdot \mathrm{s} \cdot \mathrm{cm}^{-5}$ as the definitive clinically significant cut-off for abnormal PVR in the setting of advanced liver disease (see Portopulmonary hypertension: Haemodynamics section). $1 \mathrm{mmHg} \cdot \mathrm{L}^{-1} \cdot \min =80 \mathrm{dyn} \cdot \mathrm{s} \cdot \mathrm{cm}^{-5}$.

Table 5. - Staging of severity of portopulmonary hypertension

Stage Characteristics

Mild (early)

Moderate

Severe

$$
\begin{gathered}
P \text { pa }>25-<35 \mathrm{mmHg} \\
P_{\mathrm{pa}} \geqslant 35-<45 \mathrm{mmHg} \\
P_{\mathrm{pa}} \geqslant 45 \mathrm{mmHg}
\end{gathered}
$$

Ppa: mean pulmonary arterial pressure, at rest. 
and portal hypertension [170]. Clinical series with biopsyproven cirrhosis showed a prevalence of $\mathrm{PAH}$ ranging $0.61-2.0 \%$ [88, 97, 170]. Recent studies from OLT centres have indicated a $3.1-4.7 \%$ frequency of moderate PPHTN in patients with severe liver disease [158, 171-173]. Approximately $65 \%$ of patients with $\mathrm{PAH}$ had undergone previous portosystemic surgical shunt procedures [174]. Noncirrhotic (extrahepatic) portal hypertension has been associated with up to $10 \%$ of patients with PPHTN $[174,175]$. In most series, the diagnosis of portal hypertension pre-dates the diagnosis of PPHTN, and the correlation between aetiology of liver disease, degree of portal hypertension (hepatic wedge pressure gradient), systemic haemodynamics and severity of PAH has been shown to be poor [88]. Both the US National Institutes of Health [176] and the International Primary Pulmonary Hypertension Study (IPPHS) [177], aimed at evaluating primary pulmonary hypertension $(\mathrm{PPH})$, have reported a significant proportion (7.3 and $8 \%$, respectively) of patients as having PPHTN as opposed to PPH.

In the pre-OLT era, mean and median survivals of 15 and 6 months, respectively, were reported in a literature review of PPHTN patients $(P$ pa $48 \mathrm{mmHg})[178]$. A single-centre study reported that $58 \%$ died within 1 yr of the PPHTN diagnosis. Causes of death were equally distributed between liver- and lung-related problems [88]. A 5-yr survival of 30\% was reported in a study of PPHTN patients, not treated with i.v. epoprostenol, referred to the Mayo Clinic [179]. Causes of death were equally distributed between complications of liver disease and right heart failure.

\section{Pathology}

The histopathological appearance of the pulmonary vessels in PPHTN is indistinguishable from that in other forms of PAH [2, 180-183]. Intimal proliferation and/or thickening, medial smooth muscle hypertrophy and fibrosis are seen in the small pulmonary arteries $[2,156,161]$. Thrombus with recanalisation may be present, which led authors to attribute PPHTN to emboli from the portal vein or other systemic sources [169]. It is clear that these lesions are not embolic, as they may be seen in the absence of systemic sources of clot in many forms of pulmonary hypertension [182]. This in situ thrombosis has been attributed to abnormal local endothelial thrombolytic activity and a hypercoagulable state [183]. Platelet activation may also contribute [183]. A characteristic (but not necessary) histological feature of $\mathrm{PAH}$, including PPHTN, is the plexiform lesion, which is a dilated pulmonary artery with the normal structure replaced by an intraluminal plexus of endothelial cells and slit-like vascular channels [2, $160,161]$.

\section{Pathophysiology and pathogenesis}

Vasoproliferation. The concept of a vasoproliferative process in PAH, including PPHTN, that causes increased resistance to arterial flow has been hypothesised [181]. Monoclonal proliferation of the endothelium has been documented in PPH, but not in PPHTN to date [181]. A decrease in prostacyclin (prostaglandin $\mathrm{I}_{2}$ ) expression in the pulmonary arteries of PPHTN patients has been noted [180]. Proposed factors responsible for such findings are discussed as follows. Portal hypertension induces systemic inflammatory changes and increased vascular wall shear stress, which may trigger a cascade of intracellular signals [6]. Activation or repression of various genes in the endothelial and/or smooth muscle cells may follow and this could lead to pulmonary vascular remodelling and/or vasculogenesis in genetically susceptible patients $[184,185]$. Abnormal plasma levels of vasoconstrictors (i.e. noradrenalin, rennin-angiotensin-aldosterone and arginine vasopressin) and vasodilators (i.e. NO, glucagon, vasoactive peptide and substance $\mathrm{P}$ ) have been measured in the setting of portal hypertension [186-188]. In short, investigators have hypothesised that an imbalance of vasoactive substances could reach the pulmonary circulation in abnormally high concentrations due to portosystemic shunts or defective hepatic metabolism, causing the pathological pulmonary vascular lesions seen in PPHTN [6, 153].

Genetics. Heterozygous mutations in the bone morphogenetic protein receptor type II and activin receptor-like kinase 1 genes (encoding different types of receptor member of the transforming growth factor- $\beta$ signalling superfamily) were recently reported in familial, as well as sporadic, $\mathrm{PPH}$ and $\mathrm{PAH}$ associated with hereditary haemorrhagic telangiectasia, respectively [185, 189-191]. Such receptors presumably control diverse cellular processes, including cell differentiation, endothelial/smooth muscle cell proliferation and apoptosis [190]. These abnormalities have not been found in patients with PPHTN (M. Humbert, Hôpital A Béclère, Clamart, France; personal communication, 2002).

Inflammation. The development of portosystemic shunts and dramatic decrease in the phagocytic capacity of the liver allows circulating bacteria or bacterial endotoxins from the gastrointestinal tract to enter the pulmonary circulation [192-197]. An increase in pulmonary phagocytic activity is ascribable to extensive accumulation of pulmonary intravascular macrophages that adhere to the pulmonary endothelium [6, 67, 196]. Following phagocytosis, activated macrophages release numerous cytokines, including TNF- $\beta$, growth factors and NO into the extracellular milieu [67, 196-198]. This pulmonary phagocytosis has been demonstrated in cirrhotic patients, suggesting that induction of pulmonary intravascular macrophages might contribute to the development of the pulmonary vascular disease, such as HPS and PPHTN, seen in these patients [196].

Neurohormones. Both serotonin and ET-1 are dual-action neurohormones that may cause vasoconstriction and mitogenesis in pulmonary arteries [199-202]. Their abnormal regulation of portal hypertension makes them potentially important candidates in the pathogenesis of PPHTN. Circulating levels of serotonin, a potent pulmonary vasoconstrictor, correlate with PVR in patients with PPH [199]. Serotonin predominantly originates from the enterochromaffin cells within the gastrointestinal tract wall. The lung is normally protected from high levels of free plasma serotonin by normal hepatic metabolism and the storage of serotonin in platelets [203]. Portal hypertension is associated with decreased platelet levels, reduced platelet uptake and increased levels of serotonin [203-205]. Compared with controls, patients with PPH more frequently carry the LL genetic variant of the serotonin transporter [206]. This functional insertion/deletion polymorphism results in increased serotonin transporter expression and enhanced uptake of serotonin by pulmonary artery smooth muscle cells [206]. This polymorphism has not been found in PPHTN (S. Adnot, Hôpital H Mondor, Créteuil, France; personal communication, 2003).

ET-1 is produced by the pulmonary endothelium and liver [207, 208]. Binding to $\mathrm{ET}_{\mathrm{A}}$ and $\mathrm{ET}_{\mathrm{B}}$ receptors on smooth muscle cells results in vasoconstriction and mitogenesis. Circulating ET-1 also binds to $\mathrm{ET}_{\mathrm{B}}$ receptors, resulting in 
endothelium-dependent vasodilatation, mediated by $\mathrm{NO}$ and prostaglandin $I_{2}$ production [208-211]. Increased circulating levels of ET-1 have been documented in PPH and portal hypertension without pulmonary hypertension [67, 212, 213]. Without knowing the concentration gradients across the hepatic and pulmonary circulations, it is unclear what the net effect is on the pulmonary vascular bed in the setting of advanced liver disease [208, 213].

\section{Clinical diagnosis and screening}

Symptoms and physical examination. Patients with portal hypertension who report dyspnoea, at rest or during exercise, should be assessed for the presence of PPHTN. Chest discomfort and syncope are features of advanced PPHTN. Physical examination results include elevated jugular venous pressure, an accentuated P2 component, a tricuspid regurgitation murmur, right ventricular heave or increasing lower extremity oedema (with other evidence of right-sided heart failure) [214, 215]. In the setting of advanced PPHTN, chest radiography may show increased main pulmonary artery size or cardiomegaly in the absence of other pulmonary parenchymal abnormalities [216-218]. Pulmonary function tests may show a reduced $D \mathrm{~L}, \mathrm{CO}$. Arterial blood gas levels may show mild-to-moderate hypoxaemia, an increased $\mathrm{PA}-\mathrm{a}, \mathrm{O}_{2}$ and a decreased $\mathrm{Pa}, \mathrm{CO}_{2}[156,179]$. Electrocardiography suggests right atrial enlargement, right ventricular hypertrophy or right axis deviation $[215,216]$. Conventional lung perfusion scanning may show "mosaic" perfusion, but other segmental perfusion abnormalities should prompt evaluation for pulmonary emboli [216, 217]. Specific thoracic CT scan findings for PPHTN have not been documented. B-type natriuretic peptide may be a useful serum marker of right ventricular stress [218]. To date, no data are available regarding exhaled markers [107].

Transthoracic Doppler echocardiography. Transthoracic echocardiographic findings (increased tricuspid peak regurgitant jet velocity, pulmonic valve insufficiency, paradoxical septal motion, right ventricular hypertrophydilatation and an increased right ventricular systolic pressure estimate ( $\mathrm{V}_{\text {sys }}$ ) by the Bernouilli equation) in the setting of portal hypertension suggest, but do not prove, PPHTN [175, 219-221]. Accordingly, pulmonary haemodynamic measurements by right heart catheterisation must be performed in order to confirm the diagnosis [153, 156, 219]. Lung biopsy is not advised due to increased risk of bleeding.

Screening for PPHTN is extremely important when OLT is considered [77, 164]. A retrospective analysis showed that screening Doppler echocardiography (RVsys of $>50 \mathrm{mmHg}$ ) identifies essentially all patients who should proceed to right heart catheterisation [219]. A prospective study of OLT candidates who underwent Doppler echocardiography ( $R V_{\text {sys }}$ of $>30 \mathrm{mmHg}$ ) and catheterisation measurements revealed sensitivity, specificity, and positive and negative predictive values for a diagnosis of PPHTN of $100,96,59$, and $100 \%$, respectively [221]. These studies support the value of echocardiography for screening OLT candidates for PPHTN. Therefore, transthoracic Doppler echocardiography should be the screening test of choice for OLT candidates, as recommended by the 3rd World Symposium on Pulmonary Arterial Hypertension [166]. Patients who are listed for OLT without evidence of PPHTN on initial evaluation should undergo echocardiography annually; those with PPHTN may need to be followed more frequently, at least twice or three times every year.
Haemodynamics. Right heart catheterisation is the gold standard for the diagnosis of PAH, including PPHTN [6, $153,219]$. The procedure measures pressures and flow and provides assessment of disease severity, right heart function and potential acute vasoreactivity. Haemodynamic measurements must include the following parameters: $P$ pa, mPAOP, mean right atrial pressure and $Q^{\prime}$, by either thermodilution or the Fick method, such that PVR can be calculated $[6,153]$.

Acute vasodilator testing. In $\mathrm{PPH}$, acute vasodilator testing is usually performed with either i.v. epoprostenol or inhaled NO. Although both agents exert similar effects on $P$ pa, i.v. epoprostenol produces greater increases in $Q^{\prime}$ than does NO [222, 223]. It is possible that patients with PPHTN could be less reactive to NO because liver cirrhosis is a condition of persistent endogenous NO overproduction [223-226]. Indeed, significant acute pulmonary vasodilatation has been shown in PPHTN when using higher concentrations of NO (40 ppm) [225, 226]. Accordingly, changes in selected haemodynamic parameters, such as PVR, should take into account the vasodilating agent that has been employed. Most investigators agree that acute decreases in both $P$ pa and PVR ( $>20 \%$ from baseline), with no change or increase in $Q^{\prime}$, can be considered a significant vasodilatory response $[214,215]$. The goal of such vasodilator testing is to determine staging severity and therapeutic expectations; there is no clinical relevance for calcium channel blockers use since they are contraindicated in portal hypertension (see below).

The acute vasodilatory effect of i.v. epoprostenol in PPHTN seems to be greater than that of NO. A significant decrease in pulmonary arterial pressure $(>20 \%)$ in almost half of a small subset of patients with severe PPHTN during acute infusion of i.v. epoprostenol was reported [227, 228]. In patients with PPHTN tested with both agents, the proportion of haemodynamic responders was greater when using i.v. epoprostenol than with inhaled NO (J.A. Barberà, Hospital Clínic, Barcelona, Spain; personal communication, 2003).

Pulmonary haemodynamic subsets. Unlike PPH, most patients with advanced liver disease experience a hyperdynamic circulatory state, namely increased $Q^{\prime}$ and decreased systemic vascular resistance [6, 158, 167]. In addition, some patients exhibit increased pulmonary venous volume due to systemic volume or left ventricular abnormalities. It is clinically useful, therefore, to characterise the pulmonary haemodynamics that complicate liver disease into the three following subsets on the basis of measured haemodynamic outcomes, such as $P$ pa, $Q^{\prime}$ and mPAOP, and calculated PVR, via right heart catheterisation in the stable resting state (table 6) $[6,167$, 216, 229]. 1) Hyperdynamic circulatory state. In this condition, the pulmonary vascular bed shows a minimal increase in pulmonary arterial pressure with increased $Q^{\prime}$, due to passive distension of compliant arterial vessels and recruitment of upper lung blood vessels [6, 167]; $P$ pa can increase, usually by $<35 \mathrm{mmHg}$, in response to high $Q^{\prime}$. This subgroup is the most frequent finding in liver disease, including HPS [158]. 2) Increased pulmonary venous volume. Volume increase reflects probable excess of volume and/or pressure increase due to limitation in pulmonary blood flow to the left atrium because of left ventricular dysfunction (systolic or diastolic). This results in increased mPAOP. This subset occurs in alcoholic cirrhosis, familial amyloidosis and combined liver-renal insufficiency [6, 167]. Long-standing changes may increase PVR, but not to the degree 
Table 6. - Pulmonary haemodynamic subsets most frequently associated with advanced chronic liver disease

\begin{tabular}{|c|c|c|c|c|}
\hline & $P_{\mathrm{pa}}$ & PVR & $Q^{\prime}$ & mPAOP \\
\hline Hyperdynamic circulatory state & Moderate increase & Mild decrease & Severe increase & Mild decrease \\
\hline Excess volume $^{\#}$ & Moderate increase & No change & Moderate increase & Severe increase \\
\hline $\begin{array}{l}\text { Vascular obstruction with } \\
\text { vasoproliferation }\end{array}$ & Severe increase & Severe increase & $\begin{array}{l}\text { Severe increase followed } \\
\text { by severe decrease }\end{array}$ & Mild decrease \\
\hline
\end{tabular}

All groups can be associated with increased pulmonary arterial pressures. Only the last group (i.e. vascular obstruction) is associated with vascular remodelling and characterises the entity of portopulmonary hypertension (PPHTN). Ppa: mean pulmonary arterial pressure; PVR: pulmonary vascular resistance; $Q^{\prime}$ : cardiac output; mPAOP: mean pulmonary artery occlusion pressure. ${ }^{\#}:$ e.g. hepatopulmonary syndrome; ${ }^{\uparrow}:$ e.g. PPHTN.

documented in PPHTN. The transpulmonary pressure gradient $(\mathrm{TPG}=P$ pa-mPAOP $)$ can discern between excess of volume (TPG $<10 \mathrm{mmHg}$ ) and additional pulmonary vascular abnormalities (TPG $>10 \mathrm{mmHg}$ ) [230]. 3) Vascular obstruction (i.e. PPHTN). Here, the pathological features of PPHTN include vasoconstriction and obstruction/obliteration due to endothelial proliferation, smooth muscle proliferation, fibrosis and in situ thrombosis [6, 160, 161]. The pulmonary haemodynamics in early PPHTN are unique, with markedly increased $P$ pa, PVR and $Q^{\prime}[156,163,228]$. As PVR increases, right ventricular failure ensues, characterised by falling $Q^{\prime}$.

Prognostic implications for OLT using staging of severity and pulmonary haemodynamic subsets can exist. The combination of a $P$ pa of $<35 \mathrm{mmHg}$ and a PVR of $<250$ dyn $\cdot \mathrm{s} \cdot \mathrm{cm}^{-5}$ has been associated with an excellent postOLT outcome [164]. By contrast, a $P$ pa of $>35 \mathrm{mmHg}$ has been associated with increased mortality [164, 168]. Intuitively, the measurement of right atrial pressure, right ventricular function and effects of volume loading should not be ignored [231, 232]. Figure 3 demonstrates the importance of right heart catheterisation relationships between $Q^{\prime}, P$ pa and PVR in the setting of advanced liver disease states. Most patients with significant increases in $P$ pa show reduced $Q^{\prime}$ and a PVR of $>240 \mathrm{dyn} \cdot \mathrm{s} \cdot \mathrm{cm}^{-5}$. Patients

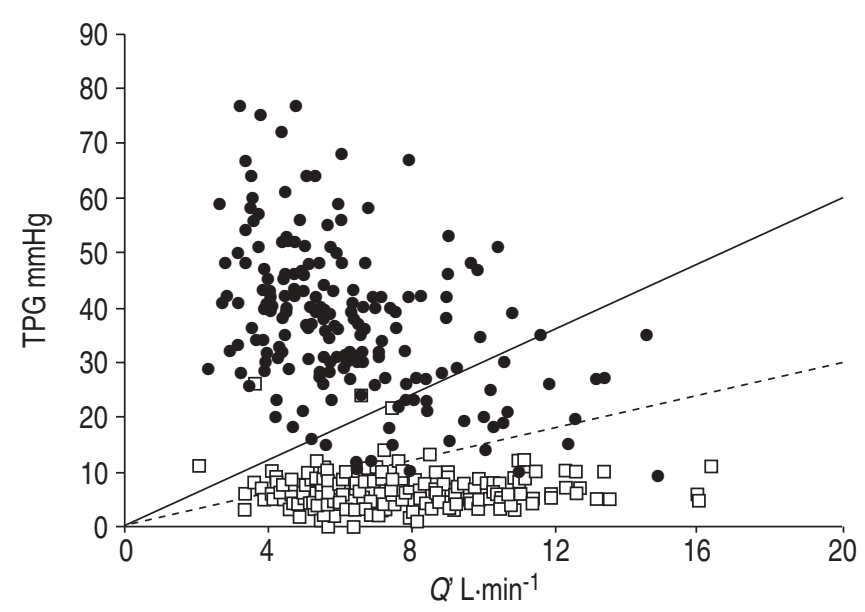

Fig. 3. - Plot demonstrating the relationship between cardiac output $\left(Q^{\prime}\right)$ and transpulmonary pressure gradient (TPG; mean pulmonary arterial pressure - mean pulmonary artery occlusion pressure) in the various ranges of calculated pulmonary vascular resistance ( - : $240 \mathrm{dyn} \cdot \mathrm{s} \cdot \mathrm{cm}^{-5}$, corresponding to the haemodynamic limit for diagnosis of portopulmonary hypertension (PPHTN); - - - : 120 dyn $\cdot \mathrm{s} \cdot \mathrm{cm}^{-5}$ ) for patients with advanced liver disease (๑: PPHTN patients; $\square$ : liver cirrhosis patients without PPHTN). Unpublished data from the combined French (463 patients; O. Sitbon, Hôpital A Béclère, Clamart, France, and Ph. Hervé), North American (64 patients; M.J. Krowka) and Spanish (54 patients; J.A. Barberà) experience. showing PVR ranging $120-240 \mathrm{dyn} \cdot \mathrm{s} \cdot \mathrm{cm}^{-5}$ were more likely to exhibit both increased TPG and increased mPAOP.

\section{Management}

Pharmacological treatment. In patients with PPHTN, thrombocytopenia and/or an increase in prothrombin time are common events [233]. Under these conditions of a high risk of gastrointestinal bleeding, oral anticoagulant therapy should not be recommended in PPHTN patients.

Nonspecific therapy. Diuretics. The goal of diuretics is to reduce both the intravascular volume and hepatic congestion that occur in patients with right-sided heart failure. Alternatively, hypovolaemia induced by an excessive amount of diuretics can reduce the $Q^{\prime}$ needed by decreasing right ventricle pre-load [233]. Furosemide and/or spironolactone (up to $400 \mathrm{mg} \cdot \mathrm{day}^{-1}$ ) should be prescribed carefully [233].

Cardiac glycosides. Digoxin has been shown to improve $Q^{\prime}$ acutely in PPH [234]. Digitoxin toxicity may be enhanced if hypoxaemia and diuretic-induced hypokalaemia are also present. The efficacy of cardiac glycosides in PPHTN patients is unknown. It is of note that $\beta$-blockers could contribute to deterioration of PPHTN.

Vasodilator therapy. Pulmonary artery vasoconstriction contributes to the pathogenesis of PAH [235-237], and has been demonstrated in PPHTN [228]. Although pure vasodilators reverse this component of the disease, they have little or no effect on the fibrotic and proliferative remodelling changes that predominate in PPHTN. Several agents are available (listed as follows).

Calcium channel blockers. Calcium channel blockers are not recommended in patients with portal hypertension as they may increase the hepatic venous pressure gradient [228, 238, 239].

Nitrates. A single case report described a patient who showed acute and chronic improvement in haemodynamics with isosorbide-5'-mononitrate [240].

Continuous i.v. epoprostenol infusion. Prostacyclin (prostaglandin $\mathrm{I}_{2}$ or epoprostenol) is a potent systemic and pulmonary vasodilator, powerful inhibitor of platelet aggregation, and possible inotrope [214, 215]. Epoprostenol can only be administered by continuous i.v. infusion (central venous access via portable infusion pump), since its half-life in the circulation is brief (3-5 min) [214, 215]. Common adverse effects attributable to epoprostenol include jaw pain, headache, diarrhoea, flush, leg pain, nausea and vomiting [239]. More serious complications 
may occur due to the delivery system (catheter-related infections or thrombosis). The interruption of infusion may be life-threatening because of the sudden loss of vasodilatation. Ascites may be related to severe right heart failure, but also to increased permeability of the peritoneal membrane promoted by epoprostenol.

Randomised clinical trials using i.v. epoprostenol have not been performed in PPHTN, but several case series have shown substantial acute short-term and long-term improvement in pulmonary haemodynamics in New York Heart Association Functional Class III and IV patients [228, 241-244]. Long-term continuous infusion of epoprostenol (up to 30 months) has resulted in significant and favourable changes in $P$ pa, PVR, $Q^{\prime}$ and the 6-min walking distance (6MWD) [228, 244]. Regarding long-term survival and the use of epoprostenol in PPHTN, preliminary data from the Mayo Clinic (Rochester, MN, USA) suggest that i.v. epoprostenol may not result in long-term survival benefit (at $5 \mathrm{yrs}$ ) compared to controls with portal hypertension, unless OLT can be accomplished [179]. As a cautionary note, continuous $i . v$. epoprostenol therapy has been followed by the development of progressive splenomegaly and worsening thrombocytopenia and leukopenia [245].

Other prostacyclin analogues (treprostinil, iloprost and beraprost). Patients with PPHTN have been treated with long-term subcutaneous infusion of treprostinil, resulting in an improved 6MWD [246]. A single patient with PPHTN was tested acutely with inhaled aerosolised iloprost, resulting in a $26 \%$ decrease in $P$ pa and $42 \%$ fall in PVR [247]. Although oral beraprost was given to patients with portal hypertension (15\% of the study population) in the Arterial Pulmonary Hypertension and Beraprost European Trial (ALPHABET), a separate data analysis was not reported [248].

Endothelin receptor antagonists (bosentan). Bosentan is an orally available dual ET $\left(\mathrm{ET}_{\mathrm{A}}\right.$ and $\left.\mathrm{ET}_{\mathrm{B}}\right)$ receptor antagonist that may cause a transient increase in hepatic enzyme levels (observed in $14 \%$ of patients in two randomised trials) [249-251]. Severe cases of acute hepatitis (one fatality) have been described with sitaxsentan, an $\mathrm{ET}_{\mathrm{A}}$-receptor-selective antagonist [250]. Since there are hepatic concerns, these agents should not be administered routinely to patients with PPHTN, but further studies in patients with minimal hepatic dysfunction are advised [249]. $\mathrm{ET}_{\mathrm{A}}$ and $\mathrm{ET}_{\mathrm{B}}$ receptor antagonists could be considered in extrahepatic portal hypertension.

Nonpharmacological treatment. Long-term oxygen therapy. Mild-to-moderate degrees of arterial hypoxaemia at rest are a common finding in PPHTN [252]. Theoretically, hypoxaemia may aggravate pulmonary hypertension by increasing pulmonary vasoconstriction, and supplemental oxygen therapy should be considered in patients with severe hypoxaemia at rest $\left(\mathrm{Pa}, \mathrm{O}_{2}<60 \mathrm{mmHg}\right)$. Severe hypoxaemia is, however, uncommon and should lead to investigation of the possibility of an intracardiac right-toleft shunt due to reopening of a patent foramen ovale [253], a possibility that can be suspected if the $\mathrm{Pa}, \mathrm{O}_{2}$ response to $100 \%$ oxygen breathing is modest $(<300 \mathrm{mmHg})$, or, alternatively, raise the coexistence of HPS.

Transjugular intrahepatic portosystemic shunt. There is no role for TIPS in PPHTN. In fact, the result of TIPS may acutely enhance pre-load and thus increase pulmonary arterial pressure and PVR [254, 255].
Orthotopic liver transplantation. Unlike HPS, PPHTN is not considered an indication for $\operatorname{OLT}[6,154,164,256]$. For those with PPHTN who have undergone OLT, the survival and change in pulmonary haemodynamics has been variable, namely worsening, unchanged, improved and normalised [152, 257-277]. Moderate-to-severe pulmonary hypertension $(P$ pa $>35 \mathrm{mmHg}$ ) places the OLT patient at increased risk of perioperative morbidity and mortality [164, 168]. Current data indicate a perioperative mortality of $>50 \%$ if OLT is carried out when $P$ pa is $35-45 \mathrm{mmHg}$ and PVR $>250 \mathrm{dyn} \cdot \mathrm{s} \cdot \mathrm{cm}^{-5}$ [168]. By contrast, there is no increase in mortality if $P$ pa is $\leqslant 35 \mathrm{mmHg}$ (158, 168]. Nonetheless, there are reports of successful OLT and long-term survival in a few patients with a $P$ pa of $>50 \mathrm{mmHg}$ and elevated PVR [265].

In a recent literature review, $>60 \%$ of patients with PPHTN were detected for the first time on the operating table, on induction of anaesthesia for OLT [168]. When a diagnosis of moderate PAH $(P$ pa $>35 \mathrm{mmHg})$ is made on the operating table, a careful assessment of the haemodynamic data must be undertaken. The diagnosis of PPHTN must be considered due to the major risks related to cardiac failure, particularly right ventricular failure and immediate graft failure as the result of venous congestion [163, 168]. In this scenario, cardiac function is best determined by transoesophageal echocardiography [232]. Indicators that would promote further therapy and cancellation of OLT surgery are poor left ventricular function, a dilated right ventricle and right atrium, and severe volume overload.

A factor to take into consideration during OLT is the $5-10 \%$ increase in $Q^{\prime}$ that may occur on reperfusion of the liver graft [232]. This increase in $Q^{\prime}$ is, however, unpredictable and may reach $\geqslant 300 \%$ in a small number (up to $3.8 \%$ ) of patients, precipitating right heart failure in a ventricle that is already under strain [232]. The increased $Q^{\prime}$ is probably the result of the removal of the obstruction to portal blood flow by the extraction of the diseased liver, together with the systemic vasodilatation caused by washout of acid metabolites

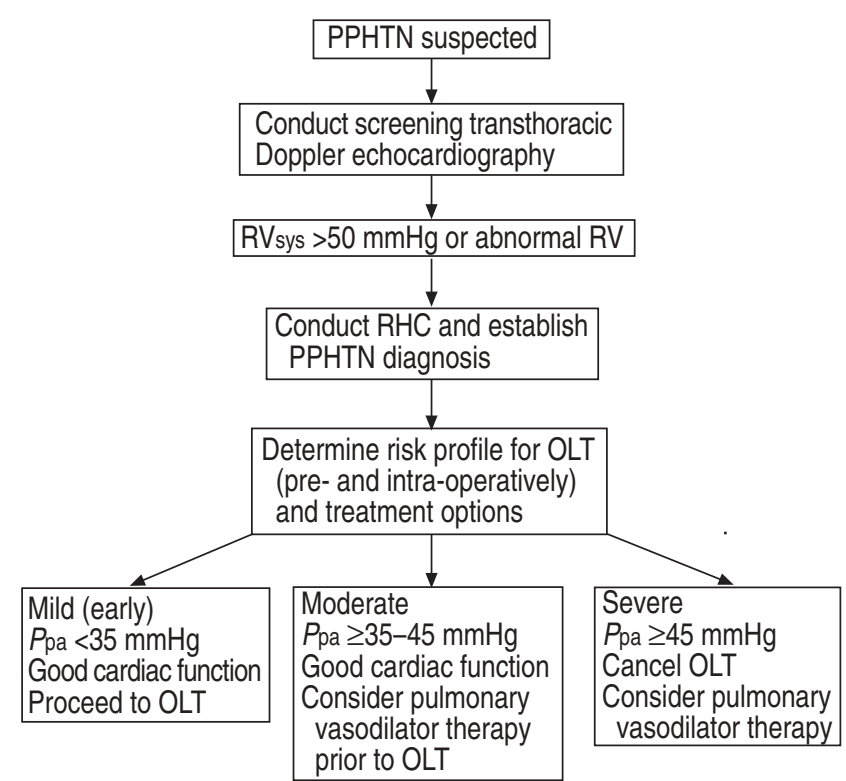

Fig. 4.-Algorithm for screening and therapeutic decisions, including orthotopic liver transplantation (OLT) consideration/management, in portopulmonary hypertension (PPHTN). RV sys: right ventricular systolic pressure; RV: right ventricle; RHC: right heart catheterisation; $P$ pa: mean pulmonary arterial pressure. 
Table 7.-Summary of major Task Force recommendations for portopulmonary hypertension (PPHTN)

Screen for PPHTN by transthoracic Doppler echocardiography. Proceed to RHC if: 1) $\mathrm{RV}_{\text {sys }}$ is $>40-50 \mathrm{mmHg}$ (cut-off may vary), or 2) RV is qualitatively abnormal and/or high suspicion for PPHTN

The diagnosis of PPHTN must be confirmed by RHC. Suggested criteria are: 1) $P$ pa of $>25 \mathrm{mmHg}$, 2) $\mathrm{mPAOP}$ of $<15 \mathrm{mmHg}$, and 3) PVR of $>240 \mathrm{dyn} \cdot \mathrm{s} \cdot \mathrm{cm}^{-5}$ (cut-off may vary)

Medical treatment of PPHTN should include case controls and multicentric clinical trials with i.v. and inhaled prostacyclin preparations. Experience should be gained in the use of phosphodiesterase inhibitors and endothelin antagonists

Severe PPHTN cannot be considered an indication for OLT at this time. Pulmonary vasodilators/vascular mediators should be used before OLT to improve and optimise pulmonary haemodynamics

RHC: right heart catheterisation; RVsys: right ventricular systolic pressure; RV: right ventricle; $P$ pa: mean pulmonary arterial pressure; mPAOP: mean pulmonary artery occlusion pressure; PVR: pulmonary vascular resistance; OLT: orthotopic liver transplantation.

and other vasodilator substances from the new graft. Patients with a relatively fixed PVR can only react to the increased flow by an acute increase in $P$ pa, with subsequent right heart failure. This unpredictable and variable response to reperfusion may be one factor explaining the different outcomes reported on patients undergoing OLT with severe PAH.

\section{Task Force recommendations}

Both PPHTN screening and haemodynamic treatment recommendations are summarised in figure 4 [163, 164, 274]. Despite clinical intervention, right heart failure may develop in the immediate post-OLT period [163, 164, 276]. The new graft is immediately compromised and the survival of the patient may be in jeopardy. It should be noted that living-donor liver transplantation [152] and heart-double lung-liver transplantation have been accomplished in highly selected patients [278]. If conventional measures fail, atrial septostomy [279] and/or the insertion of a right ventricular assist device may be life-saving [280].

The major Task Force recommendations concerning the diagnosis and treatment of PPHTN are summarised in table 7. The principal differential traits between PPHTN and HPS are set out in table 8. HPS is primarily a pulmonary gas exchange abnormality, whereas PPHTN is a major haemodynamic problem. Both entities can be clinically debilitating, and their diagnostic and therapeutic strategies are quite distinct $[153,281]$.

\section{Research prospects}

1) The genetic predisposition and mutations associated with portopulmonary hypertension and hepatopulmonary syndrome should be characterised. Similarities and distinctions as compared to the disorders of hereditary haemorrhagic telangiectasia and primary pulmonary hypertension, respectively, need to be investigated.

2) Efforts should be undertaken to identify circulating vascular mediators and their respective concentration gradients over the portal-hepatic venous and pulmonary arterialvenous circulations.

3) From a treatment perspective, further multicentric randomised trials of both the efficacy and safety of new molecules, such as oral endothelin receptor antagonists, phosphodiesterase inhibitors, serotonin transport inhibitors and inhaled prostanoids, should be considered in portopulmonary hypertension.

4) Identification of subsets of portopulmonary hypertension patients amenable to early orthotopic liver transplantation should be considered, and long-term follow-up reported.

Table 8. - Distinction between hepatopulmonary syndrome (HPS) and portopulmonary hypertension (PPHTN)

HPS

Progressive dyspnoea

Cyanosis

Finger clubbing

Spider angiomas (?)

None

ECG findings

Arterial blood gas levels

Chest radiography

CEE

${ }^{99 m}$ TcMAA shunting index

Pulmonary haemodynamics

Pulmonary angiography

OLT
Moderate-to-severe hypoxaemia Normal

Always positive; left atrial opacification for $>3-6$ cardiac cycles after right atrial opacification $\geqslant 6 \%$

Normal/low PVR

Normal/"spongy" appearance (type I)

Discrete arteriovenous communications (type II)

Always indicated in severe stages

\section{PPHTN}

RV: right ventricle; ECG: electrocardiography; RBBB: right bundle-branch block; CEE: contrast-enhanced echocardiography; ${ }^{99 m}$ TcMAA: technetium-99m-labelled macroaggregated albumin; PVR: pulmonary vascular resistance; mPAOP: mean pulmonary artery occlusion pressure; OLT: orthotopic liver transplantation. 


\begin{abstract}
Acknowledgements. The authors would like to express their gratitude to J. Bruix (Hospital Clínic, Barcelona, Spain) for facilitating the support of the European Association for the Study of the Liver (EASL) during the 2002 Madrid (Spain) workshop. They also thank L. Morte (Hospital Clínic, Barcelona, Spain) for administrative and expert secretarial assistance.
\end{abstract}

\section{References}

1. Berthelot P, Walker JG, Sherlock S, Reid L. Arterial changes in the lungs in cirrhosis of the liver-lung spider nevi. $N$ Engl J Med 1966; 274: 291-298.

2. Naeye RL. "Primary" pulmonary hypertension and coexisting portal hypertension. A retrospective study of six cases. Circulation 1960; 22: 376-384.

3. Rodriguez-Roisin R, Agustí AGN, Roca J. The hepatopulmonary syndrome: new name, old complexities. Thorax 1992; 47: 897-902.

4. Krowka MJ, Cortese DA. Hepatopulmonary syndrome: current concepts in diagnosis and therapeutic considerations. Chest 1994; 105: 1528-1537.

5. Lange PA, Stoller JK. The hepatopulmonary syndrome. Ann Intern Med 1995; 122: 521-529.

6. Hervé $\mathrm{P}$, Lebrec $\mathrm{D}$, Brenot $\mathrm{F}$, et al. Pulmonary vascular disorders in portal hypertension. Eur Respir $J$ 1998; 11: $1153-1166$.

7. Silverman A, Cooper MD, Moller JH, Good RA. Syndrome of cyanosis, digital clubbing, and hepatic disease in siblings. J Pediatr 1968; 72: 70-80.

8. Crary GS, Burke BA, Alford BA, du Cret RP, Wood BP. Radiological cases of the month. Pulmonary arteriovenous shunting in a child with cirrhosis of the liver. Am J Dis Child 1989; 143: 749-751.

9. Teuber G, Teupe C, Dietrich CF, Caspary WF, Buhl R, Zeuzem S. Pulmonary dysfunction in non-cirrhotic patients with chronic viral hepatitis. Eur J Intern Med 2002; 13: 311318.

10. Babbs C, Warnes TW, Haboubi NY. Non-cirrhotic portal hypertension with hypoxaemia. Gut 1988; 29: 129-131.

11. De BK, Sen S, Biswas PK, et al. Occurrence of hepatopulmonary syndrome in Budd-Chiari syndrome and the role of venous decompression. Gastroenterology 2002; 122: 897-903.

12. Caldwell SH, Brantley $\mathrm{K}$, Dent $\mathrm{J}$, et al., and the Hepatopulmonary Syndrome Study Group. The hepatopulmonary syndrome masquerading as pulmonary Langerhans-cell hystiocytosis. Ann Intern Med 1994; 121: 34-36.

13. Martinez GP, Barberà JA, Visa J, et al. Hepatopulmonary syndrome in candidates for liver transplantation. $J$ Hepatol 2001; 34: 651-657.

14. Schenk P, Fuhrmann V, Madl C, et al. Hepatopulmonary syndrome: prevalence and predictive value of various cut offs for arterial oxygenation and their clinical consequences. Gut 2002; 51: 853-859.

15. Cardús J, Burgos F, Díaz $\mathrm{O}$, et al. Increase in pulmonary ventilation-perfusion inequality with age in healthy individuals. Am J Respir Crit Care Med 1997; 156: 648-653.

16. Crapo RO, Jensen RL, Hegewald M, Tashkin DP. Arterial blood gas reference values for sea level and an altitude of 1,400 meters. Am J Respir Crit Care Med 1999; 160: 1525-1531.

17. Krowka MJ, Dickson ER, Cortese DA. Hepatopulmonary syndrome. Clinical observations and lack of therapeutic response to somatostatin analogue. Chest 1993; 104: 515-521.

18. Martinez G, Barberà JA, Navasa M, Roca J, Visa J, Rodriguez-Roisin R. Hepatopulmonary syndrome associated with cardiorespiratory disease. J Hepatol 1999; 30: 882-889.

19. Krowka MJ, Wiseman GA, Burnett OL, et al. Hepatopulmonary syndrome: a prospective study of relationships between severity of liver disease, $\mathrm{PaO}_{2}$ response to $100 \%$ oxygen, and brain uptake after ${ }^{99 \mathrm{~m}} \mathrm{Tc}$ MAA lung scanning. Chest 2000; 118: 615-624.

20. Egawa H, Kasahara M, Inomata $\mathrm{Y}$, et al. Long-term outcome of living related liver transplantation for patients with intrapulmonary shunting and strategy for complications. Transplantation 1999; 67: 712-717.

21. Arguedas MR, Abrams GA, Krowka MJ, Fallon MB. Prospective evaluation of outcomes and predictors of mortality in patients with hepatopulmonary syndrome undergoing liver transplantation. Hepatology 2003; 37: 192-197.

22. Krowka MJ, Porayko MK, Plevak DJ, et al. Hepatopulmonary syndrome with progressive hypoxemia as an indication for liver transplantation: case reports and literature review. Mayo Clin Proc 1997; 72: 44-53.

23. Schenk P, Schöniger-Hekele M, Furrmann V, Madl C, Silberhumer G, Müller C. Prognostic significance of the hepatopulmonary syndrome in patients with cirrhosis. Gastroenterology 2003; 125: 1042-1052.

24. Poterucha JJ, Krowka MJ, Dickson ER, Cortese DA, Stanson AW, Krom RAF. Failure of hepatopulmonary syndrome to resolve after liver transplantation and successful treatment with embolotherapy. Hepatology 1995; 21: 96-100.

25. Whyte MK, Hughes JM, Peters AM, Ussov W, Patel S, Burroughs AK. Analysis of intrapulmonary right to left shunt in the hepatopulmonary syndrome. J Hepatol 1998; 29: 85-93.

26. Krowka MJ, Mandell MS, Kawut S. Hepatopulmonary syndrome and portopulmonary hypertension: results from a multicenter database of liver transplant outcomes. Liver Transpl 2002; 8: C16 (abstract).

27. Swanson KL, Wiesner RH, Krowka MJ. Long-term survival in hepatopulmonary syndrome. Chest 2002; 122: 210S-211S (abstract).

28. Taillé C, Cadranel J, Bellocq A, et al. Liver transplantation for hepatopulmonary syndrome: a ten-year experience in Paris, France. Transplantation 2003; 75: 1482-1489.

29. Martinez-Pallí G, Barberà JA, Taurà P, Cirera I, Visa J, Rodriguez-Roisin R. Severe portopulmonary hypertension after liver transplantation in a patient with preexisting hepatopulmonary syndrome. J Hepatol 1999; 31: 1075-1079.

30. Fallon MB, Abrams GA. Pulmonary dysfunction in chronic liver disease. Hepatology 2000; 32: 859-865.

31. Mal H, Burgiere O, Durand F, Fartoukh M, Cohen-Solal A, Fournier M. Pulmonary hypertension following hepatopulmonary syndrome in a patient with cirrhosis. J Hepatol 1999; 31: $360-364$

32. Colle I, Langlet P, Barrière E, et al. Evolution of hypoxemia in patients with severe cirrhosis. $J$ Gastroenterol Hepatol 2002; 17: 1106-1109.

33. Rodriguez-Roisin R, Roca J, Agustí AGN, Mastai R, Wagner PD, Bosch J. Gas exchange and pulmonary vascular reactivity in patients with liver cirrhosis. Am Rev Respir Dis 1987; 135: 1085-1092.

34. Mélot C, Naeije R, Dechamps P, Hallemans R, Lejeune P. Pulmonary and extrapulmonary contributors to hypoxemia in liver cirrhosis. Am Rev Respir Dis 1989; 139: 632-640.

35. Genovesi MG, Tierney DF, Taplin GV, Eisenberg H. An intravenous radionuclide method to evaluate hypoxemia caused by abnormal alveolar vessels. Am Rev Respir Dis 1976; 114: 59-65.

36. Edell ES, Cortese DA, Krowka MJ, Rehder KAI. Severe hypoxemia and liver disease. Am Rev Respir Dis 1989; 140: 1631-1635.

37. Castaing $\mathrm{Y}$, Manier G. Hemodynamic disturbances and $V \mathrm{~A} /$ $Q$ matching in hypoxemic cirrhotic patients. Chest 1989; 96: 1064-1069.

38. Eriksson LS, Söderman C, Ericzon B, Eleborg L, Wahren J, Hedenstierna G. Normalization of ventilation/perfusion relationships after liver transplantation in patients with decompensated cirrhosis: evidence for a hepatopulmonary syndrome. Hepatology 1990; 12: 1350-1357. 
39. Hedenstierna G, Söderman C, Eriksson LS, Wahren J. Ventilation-perfusion inequality in patients with nonalcoholic liver cirrhosis. Eur Respir J 1991; 4: 711-717.

40. Crawford ABH, Regnis J, Laks L, Donnelly P, Engel LA, Young IH. Pulmonary vascular dilatation and diffusiondependent impairment of gas exchange in liver cirrhosis. Eur Respir J 1995; 8: 2015-2021.

41. Wagner PD. Impairment of gas exchange in liver cirrhosis. Eur Respir J 1995; 8: 1993-1995.

42. Glenny R, Wagner PD, Roca J, Rodriguez-Roisin R. Gas exchange in health: rest, exercise, and aging. In: Roca J, Rodriguez-Roisin R, Wagner PD, eds. Peripheral and pulmonary gas exchange. New York, Marcel Dekker, 2000; pp. 121-143.

43. Agustí AGN, Roca J, Rodriguez-Roisin R, Mastai R, Wagner PD, Bosch J. Pulmonary hemodynamics and gas exchange during exercise in liver cirrhosis. Am Rev Respir Dis 1989; 139: 485-491.

44. Schraufnagel D, Kay J. Structural and pathologic changes in the lung vasculature in chronic liver disease. Clin Chest Med 1996; 17: 1-15.

45. Rydell R, Hoffbauer FW. Multiple pulmonary arteriovenous fistulas in juvenile cirrhosis. Am J Med 1956; 21: 450-460.

46. Agusti AGN, Roca J, Rodriguez-Roisin R. Mechanisms of gas exchange impairment in patients with liver cirrhosis. Clin Chest Med 1996; 17: 49-66.

47. Schraufnagel D, Malik R, Goel V, Ohara N, Chang S. Lung capillary changes in hepatic cirrhosis in rats. Am J Physiol 1997; 272: L139-L147.

48. Chang SW, Ohara N. Chronic biliary obstruction induces pulmonary intravascular phagocytosis and endotoxin sensitivity in rats. J Clin Invest 1994; 94: 2009-2019.

49. Abrams GA, Jaffe CC, Hoffer PB, Binder HJ, Fallon MB. Diagnostic utility of contrast echocardiography and lung perfusion scan in patients with hepatopulmonary syndrome. Gastroenterology 1995; 109: 1283-1288.

50. Gupta D, Vijaya DR, Gupta R, et al. Prevalence of hepatopulmonary syndrome in cirrhosis and extrahepatic portal venous obstruction. Am J Gastroenterol 2001; 96: 3395-3399.

51. Binay K, Sen S, Biswas PK, Sanyal R, Jumdar DM, Biswas J. Hepatopulmonary syndrome in inferior vena cava obstruction responding to cavoplasty. Gastroenterology 2000; 118: 192-196.

52. Regev A, Yeshurun M, Rodriguez M, et al. Transient hepatopulmonary syndrome in a patient with acute hepatitis A. J Viral Hepat 2001; 8: 83-86.

53. Lee J, Menkis AH, Rosenberg HC. Reversal of pulmonary arteriovenous malformation after diversion of anomalous hepatic drainage. Ann Thorac Surg 1998; 65: 848-849.

54. Alvarez A, Ribeiro A, Hessel G, Baracat J, Ribeiro J. Abernethy malformation: one of the etiologies of hepatopulmonary syndrome. Pediatr Pulmonol 2002; 34: 391-394.

55. Vallance $\mathrm{P}$, Moncada S. Hyperdynamic circulation in cirrhosis: a role for nitric oxide? Lancet 1991; 337: 776-778.

56. Rolla G, Brussino L, Colagrande P, et al. Exhaled nitric oxide and impaired oxygenation in cirrhotic patients before and after liver transplantation. Ann Intern Med 1998; 129: 375-378.

57. Rolla G, Brussino L, Colagrande P, et al. Exhaled nitric oxide and oxygenation abnormalities in hepatic cirrhosis. Hepatology 1997; 26: 842-847.

58. Cremona G, Higenbottam TW, Mayoral V, et al. Elevated exhaled nitric oxide in patients with hepatopulmonary syndrome. Eur Respir J 1995; 8: 1883-1885.

59. Rolla G, Bucca C, Brussino L. Methylene blue in the hepatopulmonary syndrome. N Engl J Med 1994; 331: 1098.

60. Chang SW, O'Hara N. Pulmonary circulatory dysfunction in rats with biliary cirrhosis. Am Rev Respir Dis 1992; 148: 798805.

61. Fallon MB, Abrams GA, McGrath JW, Hou Z, Luo B. Common bile duct ligation in the rat: a model of intrapulmonary vasodilatation and hepatopulmonary syndrome. Am J Physiol 1997; 272: G779-G784.

62. Chang SW, Ohara N. Increased pulmonary vascular permeability in rats with biliary cirrhosis: role of thomboxane $\mathrm{A}_{2}$. Am J Physiol 1992; 264: L245-L252.

63. Fallon MB, Abrams GA, Luo B, Hou Z, Dai J, Ku DD. The role of endothelial nitric oxide synthase in the pathogenesis of a rat model of hepatopulmonary syndrome. Gastroenterology 1997; 113: 606-614.

64. Luo B, Abrams GA, Fallon MB. Endothelin-1 in the rat bile duct ligation model of hepatopulmonary syndrome: correlation with pulmonary dysfunction. J Hepatol 1998; 29: 571578.

65. Zhang M, Luo B, Chen SJ, Abrams GA, Fallon MB. Endothelin-1 stimulation of endothelial nitric oxide synthase in the pathogenesis of hepatopulmonary syndrome. $\mathrm{Am}$ J Physiol 1999; 277: G944-G952.

66. Luo B, Tang L, Ling Y, et al. Increased pulmonary vascular endothelin-B receptor expression in cirrhotic and portal hypertensive rats: a potential mechanism in experimental hepatopulmonary syndrome. Hepatology 2002; 36: 320A.

67. Nunes H, Lebrec D, Mazmanian M, et al. Role of nitric oxide in hepatopulmonary syndrome in cirrhotic rats. $\mathrm{Am}$ J Respir Crit Care Med 2001; 164: 879-885.

68. Rabiller A, Nunes H, Lebrec D, et al. Prevention of Gramnegative translocation reduces the severity of hepatopulmonary syndrome. Am J Respir Crit Care Med 2002; 166: 514-517.

69. Zhang XJ, Katsuta Y, Akimoto T, Oshuga M, Aramaki T, Takano $\mathrm{T}$. Intrapulmonary vascular dilatation and nitric oxide in hypoxemic rats with chronic bile duct ligation. J Hepatol 2003; 39: 724-730.

70. Endres S, Fulle HJ, Sinha B, et al. Cyclic nucleotides differentially regulate the synthesis of tumour necrosis factor-alpha and interleukin-1 beta by human mononuclear cells. Immunology 1991; 72: 56-60.

71. Sztrymf B, Rabiller A, Nunes $\mathrm{H}$, et al. Prevention of hepatopulmonary syndrome and hyperdynamic state by pentoxifylline in cirrhotic rats. Eur Respir J 2004; 23: 752-758.

72. Luo B, Liu L, Tang L, Zhang J, Ling Y, Fallon MB. ET-1 and TNF- $\alpha$ in HPS: analysis in prehepatic portal hypertension and biliary and nonbiliary cirrhosis in rats. $\mathrm{Am}$ J Physiol Gastrointest Liver Physiol 2004; 286: G294-G303.

73. Carter EP, Hartsfield CL, Miyazono M, Jakkula M, Morris $\mathrm{KG} \mathrm{Jr}$, McMurtry IF. Regulation of heme oxygenase-1 by nitric oxide during hepatopulmonary syndrome. $\mathrm{Am}$ J Physiol Lung Cell Mol Physiol 2002; 283: L346-L353.

74. Zhang J, Ling Y, Luo B, et al. Analysis of pulmonary heme oxygenase-1 and nitric oxide synthase alterations in experimental hepatopulmonary syndrome. Gastroenterology 2003; 125: 1441-1451.

75. Gómez FP, Martínez-Pallí G, Barberà JA, Roca J, Navasa M, Rodríguez-Roisin R. Gas exchange mechanism of orthodeoxia in hepatopulmonary syndrome. Hepatology 2004; 40: 660-666.

76. Andrivet P, Cadranel J, Housset B, Herigault R, Harf A, Adnot S. Mechanisms of impaired arterial oxygenation in patients with liver cirrhosis and severe respiratory insufficiency. Effects of indomethacin. Chest 1993; 103: 500-507.

77. Krowka MJ. Hepatopulmonary syndromes. Gut 2000; 46: 14.

78. Anel RM, Sheagren JN. Novel presentation and approach to management of hepatopulmonary syndrome with use of antimicrobial agents. Clin Infect Dis 2001; 32: E131-E136.

79. Molleston JP, Kaufman BA, Cohen A, et al. Brain abscess in hepatopulmonary syndrome. J Pediatr Gastroenterol Nutr 1999; 29: 225-226.

80. Shijo H, Sasaki H, Nishimaru K, Okumura M. Recurrent intracranial hemorrhagic episodes in hepatopulmonary syndrome. Intern Med 1992; 31: 786-790.

81. Garcia-Casasola G, Nacher J, Fernandez C, Guijarro C, Bilbao J, Zapatero A. Severe polycythemia as the first 
clinical presentation of hepatopulmonary syndrome. $J$ Clin Gastroenterol 2003; 37: 89-91.

82. Hourani JM, Bellamy PE, Tashkin DP, Batra P, Simmons MS. Pulmonary dysfunction in advanced liver disease: frequent occurrence of an abnormal diffusing capacity. Am J Med 1991; 90: 693-700.

83. Roca J, Rodriguez-Roisin R, Cobo E, Burgos F, Perez J, Clausen JL. Single-breath carbon monoxide diffusing capacity prediction equations from a mediterranean population. Am Rev Respir Dis 1990; 141: 1026-1032.

84. Ewert R, Mutze S, Schachschal G, Lochs H, Plauth M. High prevalence of pulmonary diffusion abnormalities without interstitial changes in long-term survivors of liver transplantation. Transpl Int 1999; 12: 222-228.

85. Gómez FP, Martínez-Pallí G, García-Valdecasas JC, Barberà JA, Roca J, Rodriguez-Roisin R. Incomplete gas-exchange resolution after liver transplantation in hepatopulmonary syndrome. Eur Respir J 2003; 22: Suppl. 45, 19s (abstract).

86. Stanley NN, Williams AJ, Dewar CA, Blendis LM, Reid L. Hypoxia and hydrothoraces in a case of liver cirrhosis: correlation of physiological, radiographic, scintigraphic, and pathological findings. Thorax 1977; 32: 457-471.

87. Epstein SK, Zilberberg MA, Jacoby C, Ciubotaru RL, Kaplan LM. Response to symptom-limited exercise in patients with the hepatopulmonary syndrome. Chest 1998; 114: 736-741.

88. Hadengue A, Benhayoun MK, Lebrec D, Benhamou JP. Pulmonary hypertension complicating portal hypertension: prevalence and relation to splanchnic hemodynamics. Gastroenterology 1991; 100: 520-528.

89. Kowalski HJ, Abelmann WH. The cardiac output at rest in Laennec's cirrhosis. J Clin Invest 1953; 32: 1025-1033.

90. Kontos HA, Shapiro W, Mauck HP, Patterson JL. General and regional circulatory alterations in cirrhosis of the liver. Am J Med 1964; 37: 526-535.

91. Murray JF, Dawson AM, Sherlock S. Circulatory changes in chronic liver disease. Am J Med 1958; 24: 258-267.

92. Campillo B, Bories PN, Benvenutti C, Dupeyron C. Serum and urinary nitrate levels in liver cirrhosis: endotoxinemia, renal function and hyperdynamic circulation. J Hepatol 1996; 24: 707-714.

93. Campillo B, Chabrier PE, Pelle G, et al. Inhibition of nitric oxide synthesis in the forearm arterial bed of patients with advanced cirrhosis. Hepatology 1995; 22: 1423-1429.

94. Daoud FS, Reeves JT, Schaefer JW. Failure of hypoxic vasoconstriction in patients with liver cirrhosis. J Clin Invest 1972; 51: 1076-1080.

95. Lunzer MR, Newman SP, Bernard AG, Maughani KK, Sherlock SP, Ginsburg J. Impaired cardiovascular responsiveness in liver disease. Lancet 1975; 2: 382-385.

96. Naeije R, Hallemans R, Mols P, Mélot C. Hypoxic pulmonary vasoconstriction in liver cirrhosis. Chest 1981; 80: $570-574$.

97. Naeije R, Mélot C, Hallemans R, Mols P, Lejeune P. Pulmonary hemodynamics in liver cirrhosis. Semin Respir Med 1985; 7: 164-170.

98. Vachiery F, Moreau R, Hadengue A, et al. Hypoxemia in patients with cirrhosis: relationship with liver failure and hemodynamic alterations. J Hepatol 1997; 26: 492-495.

99. Aller R, de Luis DA, Moreira V, et al. The effect of liver transplantation on circulating levels of estradiol and progesterone in male patients: parallelism with hepatopulmonary syndrome and systemic hyperdynamic improvement. $J$ Endocrinol Invest 2001; 25: 4-10.

100. Guarner C, Soriano G, Tomas A, et al. Increased serum nitrite and nitrate levels in patients with cirrhosis: relationship to endotoxemia. Hepatology 1993; 18: 1139-1143.

101. Tsoukias NM, George SC. A two-compartment model of pulmonary nitric oxide exchange dynamics. J Appl Physiol 1998; 85: 653-666.

102. Delclaux C, Mahut B, Zerah-Lancner F, et al. Increased nitric oxide output from alveolar origin during liver cirrhosis versus bronchial source during asthma. Am J Respir Crit Care Med 2002; 165: 332-337.

103. Matsumoto A, Ogura S, Hirata $\mathrm{Y}$, et al. Increased nitric oxide in the exhaled air of patients with decompensated liver cirrhosis. Ann Intern Med 1995; 123: 110-113.

104. Schenk P, Madl C, Rezale-Majd S, Lehr S, Muller C Methylene blue improves the hepatopulmonary syndrome. Ann Intern Med 2000; 133: 701-706.

105. Brussino L, Bucca C, Morello M, Scappaticci E, Mauro M, Rolla G. Effect on dyspnoea and hypoxaemia of inhaled $N^{\mathrm{G}}$. nitro-L-arginine methyl esther in hepatopulmonary syndrome. Lancet 2003; 362: 43-44.

106. Rolla G, Brussino L, Dutto L, Ottobrelli A, Bucca C. Smoking and hypoxemia caused by hepatopulmonary syndrome before and after liver transplantation. Hepatology 2001; 34: 430-431.

107. Kharitonov S, Barnes PJ. Exhaled markers of pulmonary disease. Am J Respir Crit Care Med 2001; 163: 1693-1722.

108. Krowka MJ. Hepatopulmonary syndrome and portopulmonary hypertension: distinctions and dilemmas. Hepatology 1997; 25: 1282-1284.

109. Krowka MJ, Tajik AJ, Dickson ER, Wiesner RH, Cortese DA. Intrapulmonary vascular dilatations (IVPD) in liver transplant candidates. Screening by two-dimensional contrastenhanced echocardiography. Chest 1990; 97: 1165-1170.

110. Hopkins WE, Waggoner AD, Barzilai B. Frequency and significance of intrapulmonary right-to-left shunting in endstage hepatic disease. Am J Cardiol 1992; 70: 516-519.

111. Rodriguez-Roisin R, Roca J. Hepatopulmonary syndrome: the paradigm of liver-induced hypoxaemia. Baillieres Clin Gastroenterol 1997; 11: 387-406.

112. Mimidis KP, Karatza C, Spiropoulos KV, et al. Prevalence of intrapulmonary vascular dilatations in normoxaemic patients with early liver cirrhosis. Scand $J$ Gastroenterol 1998; 33: 988-992.

113. Anand AC, Mukherjee D, Rao KS, Seth AK. Hepatopulmonary syndrome: prevalence and clinical profile. Indian $J$ Gastroenterol 2001; 20: 24-27.

114. Castro M, Krowka MJ. Hepatopulmonary syndrome: a pulmonary vascular complication of liver disease. Clin Chest Med 1996; 17: 35-48.

115. Vedrinne JM, Duperret S, Bizollon T, et al. Comparison of transesophageal and transthoracic contrast echocardiography for the detection of an intrapulmonary shunt in liver disease. Chest 1997; 111: 1236-1240.

116. Aller R, Moya JL, Moreira V, et al. Diagnosis of hepatopulmonary syndrome with contrast transesophageal echocardiography. Advantages over contrast transthoracic echocardiography. Dig Dis Sci 1999; 44: 1243-1248.

117. Aboussouan LS, Stoller JK. The hepatopulmonary syndrome. Baillieres Clin Gastroenterol 2000; 14: 1033-1048.

118. Grimon G, Andre L, Bernard O, Raffestin B, Desgrez A. Early radionuclide detection of intrapulmonary shunts in children with liver disease. J Nucl Med 1994; 35: 1328-1332.

119. Lee KN, Lee HJ, Shin WW, Webb WR. Hypoxemia and liver cirrhosis (hepatopulmonary syndrome) in eight patients: comparison of the central and peripheral pulmonary vasculature. Radiology 1999; 211: 549-553.

120. McAdams HP, Erasmus J, Crockett R, Mitchell J, Godwin JD, McDermott VG. The hepatopulmonary syndrome: radiologic findings in 10 patients. AJR Am J Roentgenol 1996; 166: 1379-1385.

121. Agustí AGN, Roca J, Bosch J, Garcia-Pagan JC, Wagner PD, Rodriguez-Roisin R. Effects of propranolol on arterial oxygenation and oxygen transport to tissues in patients with cirrhosis. Am Rev Respir Dis 1990; 142: 306-310.

122. Lambrecht GL, Malbrain ML, Coremans P, Verbist L, Verhaegen H. Orthodeoxia and platypnea in liver cirrhosis: effects of propranolol. Acta Clin Belg 1994; 49: 26-30.

123. Shijo H, Sasaki H, Yuh K, Okumura M. Effects of indomethacin on hepatogenic pulmonary angiodysplasia. Chest 1991; 99: 1027-1029. 
124. Song JY, Choi JY, Ko JT, Bae EJ, Kim HS, Noh CI. Longterm aspirin therapy for hepatopulmonary syndrome. Pediatrics 1996; 97: 917-920.

125. Cadranel J, Milleron B, Cadranel JF, et al. Severe hypoxemia associated intrapulmonary shunt in a patient with chronic liver disease: improvement after medical treatment. Am Rev Respir Dis 1992; 146: 526-527.

126. Krowka MJ, Cortese DA. Severe hypoxemia associated with liver disease: Mayo Clinic experience and the experimental use of almitrine bismesylate. Mayo Clin Proc 1987; 62: 164-173.

127. Nakos G, Evrenoglou D, Vassilakis N, Lampropoulos S. Haemodynamics and gas exchange in liver cirrhosis: the effect of orally administered almitrine bismesylate. Respir Med 1993; 87: 93-98.

128. Boker KHW, Hoper M, Lehman M, Fabel H, Manns MP. Effect of nitric oxide synthase inhibitor L-NAME on vascular resistance and arterial oxygenation in patients with hepatopulmonary syndrome. Hepatology 1994; 20: Suppl. 1, 333A (abstract).

129. Durand P, Baujard C, Grosse AL, et al. Reversal of hypoxemia by inhaled nitric oxide in children with severe hepatopulmonary syndrome, type 1, during and after liver transplantation. Transplantation 1998; 65: 437-439.

130. Maniscalco M, Sofia M, Higenbottam T. Effects of an NOsynthase inhibitor L-NMMA in the hepatopulmonary syndrome. Respiration 2001; 68: 226.

131. Anel RM, Sheagren JN. Novel presentation and approach to management of hepatopulmonary syndrome with use of antimicrobial agents. Clin Infect Dis 2001; 32: 131-136.

132. Abrams GA, Fallon MB. Treatment of hepatopulmonary syndrome with Allium sativum L. (garlic): a pilot trial. J Clin Gastroenterol 1998; 27: 232-235.

133. Saunders KB, Fernando SSD, Dalton HR, Joseph A. Spontaneous improvement in a patient with the hepatopulmonary syndrome assessed by serial exercise tests. Thorax 1994; 49: 725-727.

134. Riegler JL, Lang KA, Johnson SP, Westerman JH. Transjugular intrahepatic portosystemic shunt improves oxygenation in hepatopulmonary syndrome. Gastroenterology 1995; 109: 978-983.

135. Lasch HM, Fried MW, Zacks SL, et al. Use of transjugular intrahepatic portosystemic shunt as a bridge to liver transplantation in a patient with severe hepatopulmonary syndrome. Liver Transpl 2001; 7: 147-149.

136. Krowka MJ. Hepatopulmonary syndrome: what are we learning from interventional radiology, liver transplantation, and other disorders? Gastroenterology 1995; 109: 1009-1013.

137. Selim KM, Akriviadis EA, Zuckerman E, Chen D, Reynolds TB. Transjugular intrahepatic portosystemic shunt: a successful treatment for hepatopulmonary syndrome. $\mathrm{J}$ Am Coll Gastroenterol 1998; 93: 455-458.

138. Corley DA, Scharschmidt B, Bass N, Sonnenberg K, Gold W. Lack of efficacy of TIPS for hepatopulmonary syndrome. Gastroenterology 1997; 113: 728-731.

139. Krowka MJ, Cortese DA. Hepatopulmonary syndrome: an evolving perspective in the era of liver transplantation. Hepatology 1990; 11: 138-141.

140. Rodriguez-Roisin R, Krowka MJ. Is severe hypoxaemia due to hepatic disease an indication for liver transplantation? A new therapeutic approach. Eur Respir J 1994; 7: 839-842.

141. Fewtrell MS, Noble-Jamieson G, Revell S, et al. Intrapulmonary shunting in the biliary atresia/polysplenia syndrome: reversal after liver transplantation. Arch Dis Child 1994; 70: 501-504.

142. Battaglia SE, Pretto JJ, Irving LB, Jones RM, Angus PW. Resolution of gas exchange abnormalities and intrapulmonary shunting following liver transplantation. Hepatology 1997; 25: 1228-1232.

143. Krowka MJ. Hepatopulmonary syndrome: recent literature (1997 to 1999) and implications for liver transplantation. Liver Transpl 2000; 6: Suppl. 1, S31-S35.
144. De Goyet JV, Gibbs P, Clauyput P, Reding R, Sokal EM, Otte JB. Original extrahepatic approach for hepatic portal revascularization and relief of portal hypertension related to late portal vein thrombosis after liver transplantation. Transplantation 1996; 62: 71-75.

145. Collisson EA, Nourmand H, Fraiman MH, et al. Retrospective analysis of the results of liver transplantation for adults with severe hepatopulmonary syndrome. Liver Transpl 2002; 8: 925-931.

146. Van Obbergh L, Carlier M, De Clety SC, et al. Liver transplantation and pulmonary gas exchanges in hypoxemic children. Am Rev Respir Dis 1993; 148: 1408-1410.

147. Hobeika J, Houssin D, Bernard O, Devictor D, Grimon G, Chapuis Y. Orthotopic liver transplantation in children with severe liver disease and severe hypoxemia. Transplantation 1994; 57: 224-228.

148. Laberge JM, Brandt ML, Leberque $\mathrm{P}$, et al. Reversal of cirrhosis-related pulmonary shunting in two children by orthotopic liver transplantation. Transplantation 1992; 53: $1135-1138$.

149. United Network for Organ Sharing. UNOS Policy 3.6 (Appendix 3B "Indications for liver transplantation in children"). www.optn.org. Date last updated: June 252004. Date last accessed: July 272003.

150. Avendano CE, Flume PA, Baliga P, Lewin DN, Strange C, Reuben A. Hepatopulmonary syndrome occurring after orthotopic liver transplantation. Liver Transpl 2001; 7: 1081-1084.

151. Krowka MJ, Wiseman GA, Steers JL, Wiesner RH. Late recurrence and rapid evolution of severe hepatopulmonary syndrome after liver transplantation. Liver Transpl 1999; 5: 451-453.

152. Kikuchi H, Ohkohchi N, Orii T, Satomi S. Living-related liver transplantation in patients with pulmonary vascular disease. Transplant Proc 2000; 32: 2177-2178.

153. Krowka MJ. Portopulmonary hypertension: diagnostic advances and caveats. Liver Transpl 2003; 9: 1336-1337.

154. Groves BM, Brundage BH, Elliot CG, et al. Pulmonary hypertension associated with hepatic cirrhosis. In: Fishman AP, ed. The pulmonary circulation: normal and abnormal. Philadelphia, University of Pennsylvania Press, 1990; pp. 359-369.

155. Lockhart A. Pulmonary arterial hypertension in portal hypertension. Clin Gastroenterol 1985; 14: 123-138.

156. Kuo PC, Plotkin JS, Gaine S, et al. Portopulmonary hypertension and the liver transplant candidate. Transplantation 1999; 67: 1087-1093.

157. Rich S, Dantzker DR, Ayres SM, et al. Primary pulmonary hypertension: a national prospective study. Ann Intern Med 1987; 107: 216-223.

158. Castro M, Krowka M, Schroeder D, et al. Frequency and clinical implications of increased pulmonary artery pressures in liver transplantation. Mayo Clin Proc 1996; 71: 543-551.

159. Kuo PC, Schroeder RA, Vagelos RH, et al. Volumemediated pulmonary responses in liver transplant candidates. Clin Transplant 1996; 10: 521-527.

160. Krowka MJ, Edwards WD. A spectrum of pulmonary vascular pathology in portopulmonary hypertension. Liver Transpl 2000; 6: 2421-2422.

161. Ruttner JR, Bartschi JP, Niedermann R, Schneider J. Plexogenic arteriopathy and liver cirrhosis. Thorax 1980; 35: 133-136.

162. Mandell SM, Krowka MJ. National hepatopulmonary syndrome/portopulmonary hypertension database for liver transplant candidates. Anesthesiology 1997; 87: 450-451.

163. Ramsay MAE, Simpson BR, Nguyen AT, Ramsay KJ, East C, Klintmalm GB. Severe pulmonary hypertension in liver transplant candidates. Liver Transpl Surg 1997; 3: 494-500.

164. Budhiraja R, Hassoun PM. Portopulmonary hypertension: a tale of two circulations. Chest 2003; 123: 562-576.

165. Naeije R. Hepatopulmonary syndrome and portopulmonary hypertension. Swiss Med Wkly 2003; 133: 163-169. 
166. Simmoneau G, Galie N, Rubin LJ, et al. Clinical classification of pulmonary hypertension. J Am Coll Cardiol 2004; 43: $5 \mathrm{~S}-12 \mathrm{~S}$.

167. Chemla D, Castelain V, Hervé P, Lecarpentier Y, Brimioulle S. Haemodynamic evaluation of pulmonary hypertension. Eur Respir J 2002; 20: 1314-1331.

168. Krowka MJ, Plevak DJ, Findlay JY, Rosen CB, Wiesner RH, Krom RAF. Pulmonary hemodynamics and perioperative cardiopulmonary mortality-related mortality in patients with portopulmonary hypertension undergoing liver transplantation. Liver Transpl 2000; 6: 443-450.

169. Mantz F, Craige E. Portal axis thrombosis with spontaneous portocaval shunt and cor pulmonale. Arch Pathol 1951; 52: 91-97.

170. McDonnell PJ, Toye PA, Hutchins GM. Primary pulmonary hypertension and cirrhosis: are they related? Am Rev Respir Dis 1983; 127: 437-441.

171. Taura P, Garcia-Valdecasas JC, Beltran J, et al. Moderate pulmonary hypertension in patients undergoing liver transplantation. Anesth Analg 1996; 83: 675-680.

172. Yang YY, Lin HC, Hou MC, Lee FY, Chang FY, Lee SD. Portopulmonary hypertension: distinctive hemodynamic and clinical manifestations. J Gastroenterol 2001; 36: 181186.

173. Torregossa M, Genesca J, Gonzalez A, et al. Role of Doppler echocardiography in the assessment of portopulmonary hypertension in liver transplantation candidates. Transplantation 2001; 71: 572-574.

174. Lebrec D, Capron JP, Benhamou JP. Primary pulmonary hypertension and portal hypertension. Am Rev Respir Dis 1979; 120: 849-856.

175. Portmann R, Stewart S, Higenbottam TW, Clayton PT, Lloyd JK, Williams R. Nodular transformation of the liver associated with portal and pulmonary artery hypertension. Gastroenterology 1993; 104: 616-621.

176. D'Alonzo GE, Barst RJ, Ayres SM, et al. Survival in patients with pulmonary hypertension. Ann Intern Med 1991; 114: 343-349.

177. Abenhaim L, Moride $\mathrm{Y}$, Rich S, et al. The International Primary Pulmonary Hypertension Study (IPPHS). Chest 1994; 105: 37S-41S.

178. Robalino BD, Moodie DS. Association between primary pulmonary hypertension and portal hypertension: analysis of its pathophysiology, clinical laboratory and hemodynamic manifestations. J Am Coll Cardiol 1992; 17: 492-499.

179. Swanson KL, McGoon MD, Krowka MJ. Survival in portopulmonary hypertension. Am J Respir Crit Care Med 2003; 167: A683 (abstract).

180. Lee SD, Shroyer KR, Markham NE, Cool CD, Voelkel NF, Tuder RM. Monoclonal endothelial cell proliferation is present in primary but not secondary pulmonary hypertension. J Clin Invest 1998; 101: 927-934.

181. Tuder RM, Cool CD, Geraci MW, et al. Prostacyclin synthase expression is decreased in lungs from patients with pulmonary hypertension. Am J Respir Crit Care Med 1999; 159: 1925-1932.

182. Wagenvort CA, Mulder PG. Thrombotic lesions in primary plexogenic arteriopathy. Similar pathogensis or complication? Chest 1993; 103: 844-849.

183. Sankey EA, Crow J, Mallot SV, et al. Pulmonary platelet aggregates: possible cause of sudden perioperative death in adults undergoing liver transplantation. J Clin Path 1993; 46: 222-227.

184. Lane KB, Machado RD, Pauciulo MW. Heterozygous germline mutations in BMPR2 encoding a TGF- $\beta$ receptor causes familial primary pulmonary hypertension. Nat Genet 2000; 26: 81-84.

185. Trembath RC, Thompson JR, Machado RD, et al. Clinical and molecular genetic features of pulmonary hypertension in patients with hereditary hemorrhagic telangiectasia. $N$ Engl $J$ Med 2001; 345: 325-334.

186. Moller S, Hendriksen JH. Circulatory abnormalities in cirrhosis with focus on neurohumoral aspects. Semin Nephrol 1997; 17: 505-519.

187. Cahill PA, Redmond EM, Sitzmann JV. Endothelial dysfunction in cirrhosis and portal hypertension. Pharmacol Ther 2001; 89: 273-293.

188. Battista S, Bar F, Mengozzi G, Zanon E, Grosso M, Molino G. Hyperdynamic circulation in patients with cirrhosis: direct measurement of nitric oxide levels in hepatic and portal veins. J Hepatol 1997; 26: 75-80.

189. Deng Z, Morse JH, Slager SL. Familial primary pulmonary hypertension (gene PPH1) is caused by mutations in the bone morphogenetic protein receptor-II gene. Am J Hum Genet 2000; 67: 737-744.

190. Morse JH, Deng Z, Knowles JA. Genetic aspects of pulmonary arterial hypertension. Ann Med 2001; 33: 596-603.

191. Harrison RE, Flanagan JA, Sankela M, et al. Molecular and functional analysis identifies ALK-1 as the predominant cause of pulmonary hypertension related to hereditary hemorrhagic telangiectasia. J Med Genet 2003; 40: 865-871.

192. Humbert M, Monti G, Brenot F, et al. Increased interleukin1 and interleukin-6 levels in severe primary pulmonary hypertension. Am J Respir Crit Care Med 1995; 151: 1628-1631.

193. Lee FY, Lu RH, Tsai YT, Liao TM, Lin TF, Wang SS. Plasma interleukin-6 levels in patients with cirrhosis. Relationship to endotoxemia, tumor necrosis factor- $\alpha$, and hyperdynamic circulation. Scand J Gastroenterol 1996; 31: 500-505.

194. Tilg H, Wilmer A, Vogel W. Serum levels of cytokines in chronic liver diseases. Gastroenterology 1992; 103: 264 274.

195. Miot-Noirault E, Faure L, Guichard Y, Montharu J, LePape A. Scintographic in vivo assessment of the development of pulmonary intravascular macrophages in liver disease: experimental study in rats with biliary cirrhosis. Chest 2000; 120: 941-947.

196. Keyes JW, Wilson GA, Quinonest JD. An evaluation of lung uptake of colloid during liver imaging. J Nucl Med 1973; 14 : 687-691.

197. Laffy G, Foschi M, Simoni A, LaVilla G, Barletta G, Mannaioni PF. Increased production of nitric oxide by neutrophils and monocytes from patients with ascites and hyperdynamic circulation. Hepatology 1995; 22: 16661673.

198. Clement B, Musso O, Lietard J, Theret N. Homeostatic control of angiogenesis: a newly identifed function of the liver? Hepatology 1999; 29: 621-623.

199. Kereveu A, Callebert J, Humbert M. High plasma serotonin levels in primary pulmonary hypertension. Arterioscler Thromb Vasc Biol 2000; 20: 2233-2239.

200. Stewart DJ, Levy RD, Cernacek P, Langleben D. Increased plasma endothelin-1 in pulmonary hypertension. Ann Intern Med 1991; 114: 464469.

201. Laffi G, Marra F, Gresele P. Evidence for a storage pool defect in platelets from cirrhotic patients with defective aggregation. Gastroenterology 1992; 103: 641-646.

202. Beaudry P, Hadangue A, Callbert J. Blood and plasma 5hydroxytryptamine levels in patients with cirrhosis. Hepatology 1994; 20: 800-803.

203. Ahtee L, Briley M, Raisman R, Lebrec D, Langer SZ. Reduced uptake of serotonin but unchanged ${ }^{3} \mathrm{H}$-impiramine binding in the platelets from cirrhotic patients. Life Sci 1981; 29: 2323-2329.

204. Hervé P, Launay JM, Scrobohaci ML. Increased plasma serotonin in primary pulmonary hypertension. Am J Med 1995; 99: 249-254.

205. Anderson GM, Stevenson JM, Cohen DJ. Steady-state model for plasma free and platelet serotonin. Life Sci 1987; 41: 1777-1785.

206. Eddahibi S, Humbert M, Fadel E, et al. Serotonin transporter overexpression is responsible for pulmonary artery smooth muscle hyperplasia in primary pulmonary hypertension. J Clin Invest 2001; 108: 1141-1150. 
207. Bernardi M, Gulberg V, Colantoni A, Trevisani F, Gasbarrini AJ, Gerbes AL. Plasma endothelin-1 and -3 in cirrhosis: relationship with systemic hemodynamics, renal function, and neurohumoral systems. J Hepatol 1996; 24: 161-168.

208. Gerbes AL, Moller S, Gulberg V, Henriksen JH. Endothelin1 and -3 plasma concentrations in patients with cirrhosis: role of splanchnic and renal passage and liver function. Hepatology 1995; 21: 735-739.

209. Salo J, Francitorra A, Folloa A, et al. Increased plasma endothelin in cirrhosis. Relationship with systemic endotoxemia and response to changes in effective blood volume. J Hepatol 1995; 22: 389-398.

210. Moller S, Emmeluth C, Henriksen JH. Elevated circulating plasma endothelin-1 concentrations in cirrhosis. $J$ Hepatol 1993; 19: 285-290.

211. Matsumoto H, Uemasu J, Kitano M, Kawasaki H. Clinical significance of plasma endothelin-1 in patients with chronic liver disease. Dig Dis Sci 1994; 39: 2665-2670.

212. Veglio F, Pinna G, Melchio R, et al. Plasma endothelin levels in cirrhotic subjects. J Hepatol 1992; 15: 85-87.

213. Kamath PS, Carpenter HA, Lloyd RV, et al. Hepatic localization of endothelin-1 in patients with idiopathic portal hypertension and cirrhosis of the liver. Liver Transpl 2000; 6: 596-602.

214. Krowka MJ. Pulmonary hypertension. Mayo Clin Proc 2000; 75: 625-630.

215. Gaine S. Pulmonary hypertension. JAMA 2000; 284: 31603168.

216. Kuo PC, Plotkin JS, Johnson LB, et al. Distinctive clinical features of portopulmonary hypertension. Chest 1997; 112: 980-986.

217. Chan T, Palevsky HI, Miller WT. Pulmonary hypertension complicating portal hypertension: findings on chest radiographs. AJR Am J Roentgenol 1988; 151: 909-914.

218. Nagaya $\mathrm{N}$, Nishikimi $\mathrm{T}$, Okano $\mathrm{Y}$, et al. Plasma brain natriuretic peptide levels increase in proportion to the extent of right ventricular dysfunction in pulmonary hypertension. J Am Coll Cardiol 1998; 31: 201-211.

219. Kim WR, Krowka MJ, Plevak DJ, et al. Accuracy of Doppler echocardiography in the assessment of pulmonary hypertension in liver transplant candidates. Liver Transpl 2000; 6: 453-458

220. Donovan CL, Marcovitz PA, Punch JD, et al. Twodimensional and dobutamine stress echocardiography in the preoperative assessment of patients with end-stage liver disease prior to orthotopicliver transplantation. Transplantation 1996; 61: 1180-1188.

221. Colle IO, Moreau R, Godinho E, et al. Diagnosis of portopulmonary hypertension in candidates for liver transplantation: a prospective study. Hepatology 2003; 37: 401-409.

222. Sitbon O, Brenot F, Denjean A, et al. Inhaled nitric oxide as a screening vasodilator agent in primary pulmonary hypertension. A dose-response study and comparison with prostacyclin. Am J Respir Crit Care Med 1995; 151: 384-389.

223. Morales J, Santos S, de Jover L, et al. Clinical value of vasodilator test with inhaled nitric oxide for predicting longterm response top oral vasodilators in pulmonary hypertension. Respir Med 2004; 98: 225-234.

224. Fallon MB. Portopulmonary hypertension: new clinical insights and more questions on pathogenesis. Hepatology 2003; 37: 253-255.

225. Whittle BJ, Moncada S. Nitric oxide: the elusive mediator of the hyperdynamic circulation of cirrhosis? Hepatology 1992; 16: 1089-1092.

226. Findlay JF, Harrison BA, Plevak DJ, Krowka MJ. Inhaled nitric oxide reduces pulmonary artery pressures in portopulmonary hypertension. Liver Transpl 1999; 5: 381-387.

227. Plotkin JS, Kuo PC, Rubin LJ, et al. Successful use of chronic epoprostenol as a bridge to liver transplantation in severe portopulmonary hypertension. Transplantation 1998; 65: $457-459$.
228. Krowka MJ, Frantz RP, McGoon MD, Severson C, Plevak DJ, Wiesner RH. Improvement in pulmonary hemodynamics during intravenous epoprostenol (prostacyclin): a study of 15 patients with moderate to severe portopulmonary hypertension. Hepatology 1999; 30: 641-648.

229. Nunn JF. Nunn's Applied Respiratory Physiology. 5th Edn. Oxford, Butterworth-Heinemann, 2002; pp. 138-155.

230. Castelain V, Chemla D, Humbert M, et al. Pulmonary artery pressure-flow relations after prostacyclin in primary pulmonary hypertension. Am J Respir Crit Care Med 2002; 165: 338-340.

231. De Wolf AM, Gasior T, Kang Y. Pulmonary hypertension in a patient undergoing liver transplantation. Transplant Proc 1991; 23: 2000-2001.

232. Ramsay MAE. Perioperative mortality in patients with portopulmonary hypertension undergoing liver transplantation. Liver Transpl 2000; 6: 451-452.

233. Bosch J, D' Amico G, Garcia-Pagan JC. Portal hypertension. In: Schiff ER, Dorrell MF, Maddrey WC, eds. Schiff's Diseases of the Liver. 9th Edn. Philadelphia, Lippincott Williams \& Wilkins, 2003; pp. 429-486.

234. Rich S, Seidlitz M, Dodin E, McLaughlin V, Francis G. The short-term effects of digoxin in patients with right ventricular dysfunction from pulmonary hypertension. Chest 1998; 114: 787-792.

235. Naeije R, Vachiery JL. Medical therapy of pulmonary hypertension. Clin Chest Med 2001; 22: 517-528.

236. Rubin LJ. Primary pulmonary hypertension. $N$ Engl J Med 1997; 336: 111-117.

237. Rich S, Kaufmann E, Levy PS. The effect of high doses of calcium-channel blockers on survival in primary pulmonary hypertension. N Engl J Med 1992; 327: 76-81.

238. Ota K, Shilo H, Kokawa H, et al. Effects of nidefipine on hepatic venous pressure gradient and portal vein blood flow in patients with cirrhosis. J Gastroenterol Hepatol 1995; 10: 198-204.

239. Navasa $\mathbf{M}$, Bosch $\mathbf{J}$, Reichen $\mathrm{J}$, et al. Effects of verapamil on hepatic and systemic hemodynamics and liver function in patients with cirrhosis and portal hypertension. Hepatology 1988; 8: 850-854.

240. Ribas J, Angrill J, Barberà JA, et al. Isosorbide-5-mononitrate in the treatment of pulmonary hypertension associated with portal hypertension. Eur Respir J 1999; 13: 210-212.

241. Rich S, McLaughlin VV. The effects of chronic prostacyclin therapy on cardiac output and symptoms in primary pulmonary hypertension. J Am Coll Cardiol 1999; 34: 1184-1187.

242. McLaughlin VV, Genthner DE, Panella MM, Rich S. Reduction in pulmonary vascular resistance after long-term epoprostenol (prostacyclin) therapy in primary pulmonary hypertension. N Engl J Med 1998; 338: 273-277.

243. Kuo PC, Johnson LB, Plotkin JS, Howell CD, Bartlett CD, Rubin LJ. Continuous intravenous infusion of epoprostenol for the treatment of portopulmonary hypertension. Transplantation 1997; 63: 604-606.

244. Rafaran AL, Maurer J, Metha AC, Schilz R. Progressive portopulmonary hypertension after liver transplantation treated with epoprostenol. Chest 2000; 118: 1497-1500.

245. Findlay JY, Plevak DJ, Krowka MJ. Progressive splenomegaly after epoprostenol therapy for portopulmonary hypertension. Liver Transpl 1999; 5: 362-365.

246. Benza RL, Tallaj JA, Rayburn BK, Foley BA, Bourge RC. Safety and efficacy of treprostinil in cirrhosisrelated pulmonary artery hypertension. Hepatology 2003; 38: A530.

247. Halank M, Marx C, Usicenko S, Opitz C, Winkler J, Ewert R. Inhaled iloprost for patients with portopulmonary hypertension. Am J Respir Crit Care Med 2003; 167: A277 (abstract).

248. Galie N, Humbert M, Vachiery JL, for the Arterial Pulmonary Hypertension and Beraprost European Trial (ALPHABET) Study Group. Effects of beraprost sodium, an 
oral prostacyclin analogue, in patients with pulmonary arterial hypertension: a randomized, double-blind, placebo controlled trial. J Am Coll Cardiol 2002; 39: 1496-1502.

249. Sitbon O, Badesch DB, Channik RN, et al. Effects of the dual endothelin receptor antagonist bosentan in patients with pulmonary artery hypertension. Chest 2003; 124: 247254.

250. Barst RJ, Rich S, Widlitz A, Horn EM, McLaughlin VV, McFarlin J. Clinical efficacy of sitaxsentan, an endothelin receptor-A antagonist, in pulmonary arterial hypertension. Chest 2002; 121: 1860-1868.

251. Van Giersbergen PLM, Popescu G, Bodin F, Dingemanse J. Influence of mild liver impairment on the pharmacokinetics and metabolism of bosentan, a dual endothelin receptor antagonist. J Clin Pharmacol 2003; 43: 15-22.

252. Swanson KL, Krowka MJ. Arterial oxygenation associated with portopulmonary hypertension. Chest 2002; 121: 18691875.

253. Raffy O, Sleiman C, Vachiery F, et al. Refractory hypoxemia during liver cirrhosis: hepatopulmonary syndrome or "primary" pulmonary hypertension. Am J Respir Crit Care Med 1996; 153: 1160-1171.

254. Azoulay D, Castaing Y, Dennison A, Martino W, Eyraud D, Bismuth $\mathrm{H}$. Transjugular intrahepatic portosystemic shunt worsens the hyperdynamic circulatory state of the cirrhotic patient. Hepatology 1994; 19: 129-132.

255. Van der Linden P, Le Moine O, Ghysels M, Ortinez M, Deviere J. Pulmonary hypertension after transjugular intrahepatic portosystemic shunt: effects on right ventricular function. Hepatology 1996; 23: 982-987.

256. Krowka MJ. Pulmonary hypertension, (high) risk of liver transplantation, and some lessons from "primary" pulmonary hypertension. Liver Transpl 2002; 8: 389-390.

257. DeWolf AM, Scott VL, Gasior T, Kang Y. Pulmonary hypertension and liver transplantation. Anesthesiology 1993; 78: 213-214.

258. Cheng EY, Woehlck HJ. Pulmonary artery hypertension complicating anesthesia for liver transplantation. Anesthesiology 1992; 77: 389-392.

259. Prager MC, Cauldwell CA, Ascher NL, Roberts JP, Wolf CL. Pulmonary hypertension associated with liver disease is not reversible after liver transplantation. Anesthesiology 1992; 77: 375-378.

260. Yoshida EM, Erb SR, Pflugfelder PW, et al. Single lung versus liver transplantation for the treatment of portopulmonary hypertension: a comparison of two patients. Transplantation 1993; 55: 688-690.

261. Scott V, DeWolf A, Kang Y, et al. Reversibility of pulmonary hypertension after liver transplantation. Transplant Proc 1993; 25: 789-790.

262. Koneru B, Ahmed S, Weisse AB, Grant GP, McKim KA. Resolution of pulmonary hypertension of cirrhosis after liver transplantation. Transplantation 1994; 58: 1133-1135.

263. Pilatus N, Jacobs L, Rerkpattanapipat P, et al. Clinical predictors of pulmonary hypertension in patients undergoing liver transplantation. Liver Transpl 2000; 6: 85-91.

264. Losay J, Piot D, Bougaran J, et al. Early liver transplantation is crucial in children with liver disease and pulmonary artery hypertension. J Hepatol 1998; 30: 337-342.

265. Starkel P, Vera A, Gunson B, Mutimer D. Outcome of liver transplantation for patients with pulmonary hypertension. Liver Transpl 2002; 8: 382-388.

266. Liu G, Knudsen KE, Secher NH. Orthotopic liver transplantation in a patient with primary pulmonary hypertension. Anaesth Intensive Care 1996; 24: 714-716.

267. Ramsay MAE, Spikes C, East CA, et al. The perioperative management of portopulmonary hypertension with nitric oxide and epoprostenol. Anesthesiology 1999; 90: 299-301.

268. Kaspar MD, Ramsay MAE, Shuey CB, Levy MF, Klintmalm GB. Severe pulmonary hypertension and amelioration of severe hepatopulmonary syndrome after liver transplantation. Liver Transpl Surg 1998; 4: 177-179.

269. Tarquino M, Geggel RL, Strauss RS, Rhodes RS, Wunderlich B, Rohrer RJ. Treatment of pulmonary hypertension with inhaled nitric oxide during hepatic transplantation in an adolescent: reversibility of pulmonary hypertension after transplantation. Clin Pediatr (Phila) 1998; 37: 505-509.

270. Tan HP, Markowitz JS, Montgomery RA, et al. Liver transplantation in patients with severe portopulmonary hypertension treated with preoperative chronic intravenous epoprostenol. Liver Transpl 2001; 7: 745-749.

271. Schott R, Chaouat A, Launy A, Pottecher T, Weitzenblum E. Improvement in pulmonary hypertension after liver transplantation. Chest 1999; 115: 1748-1749.

272. Mair P, Kaehler CH, Pomaroli A, Schwarz B, Vogel W, Margreiter R. Orthotopic liver transplantation in a patient with severe portopulmonary hypertension. Acta Anaesthesiol Scand 2001; 45: 513-518.

273. Tominaga M, Furutani H, Segawa H, et al. [Perioperative management of living-donor liver transplants in 2 patients with severe portopulmonary hypertension]. Masui 2003; 52: 729-731.

274. Koneru B, Fisher A, Wilson DJ, Klein KM, De la Torre AN, Seguel J. De novo diagnosis of portopulmonary hypertension. Am J Transplant 2002; 2: 883-886.

275. Kett DH, Acosta RC, Campos MA, Rodriguez MJ, Quartin AA, Schein RMH. Recurrent portopulmonary hypertension after liver transplantation: management with epoprostenol and resolution after retransplantation. Liver Transpl 2001; 7 : 645-648.

276. Cotton CL, Gandhi S, Vaitkus PT, et al. Role of echocardiography in detecting pulmonary hypertension in liver transplant candidates. Liver Transpl 2002; 8: 1051-1054.

277. Krowka MJ, Mandell SM, Ramsay MAE, et al. A report of the hepatopulmonary syndrome/portopulmonary hypertension database for liver transplant candidates: arterial oxygenation and pulmonary hemodynamics in those "denied" versus those transplanted. Liver Transpl 2004; 10: 174-182.

278. Pirenne J, Verleden G, Nevens F, et al. Combined liver and heart-lung transplantation in liver transplant candidates with refractory portopulmonary hypertension. Transplantation 2002; 73: 140-142.

279. Sandoval J, Rothman A, Pulido T. Atrial septostomy for pulmonary hypertension. Clin Chest Med 2001; 22: 547-560.

280. Lima LE, Jatene F, Buffolo E, et al. A multicenter initial clinical experience with right heart support and beating heart coronary surgery. Heart Surg Forum 2000; 4: 60-64.

281. Hoeper M, Krowka MJ, Strassbourg CP. Portopulmonary hypertension and hepatopulmonary syndrome. Lancet 2004; 363: 1461-1468. 